\title{
LINGUISTIC TERMS DESCRIBING DIFFERENT TYPES OF ARMOUR IN PERSIAN MANUSCRIPTS
}

\author{
TERMINOLOGÍA SOBRE DIFERENTES TIPOS DE ARMAMENTO DEFENSIVO EN \\ MANUSCRITOS PERSAS
}

POR

Manouchehr Moshtagh Khorasani*

\begin{abstract}
Resumen
The present article investigates different terms describing armour and its diverse typology in Persian martial tradition taken from a selected number of 47 dated Persian manuscripts from the $10^{\text {th }}$ to the $19^{\text {th }}$ centuries C.E. Both human and animal armour used in battlefields are described.
\end{abstract}

El presente artículo describe, a partir de 47 manuscritos persas datados entre el siglo X y el siglo XIX d.C., los diversos términos que han designado las armaduras y sus diversas tipologías en la tradición marcial persa, tanto en lo que se refiere a armaduras para hombres como aquellas elaboradas para los animales de batalla.

\section{Keywords - Palabras Clave}

Armour; Armguard; Shin Protector; Thigh Protector; Helmet; Mail Armour; Horse Armour; Elephant armour. Elefante.

Armadura; Guardabrazo; Grebas; Musleras; Casco; Cota de Malla; Armadura de Calballo; Armadura de

\section{INTRODUCTION}

Persian manuscripts often mention different types of armour worn by warriors on the battlefield. To the readers of epic stories, historical books and manuscripts, and poems, these terms present an enigma as without a thorough understanding of the shape and function of different types of armour and their proper historical usage, readers will not be able to understand the texts properly. The goal of this article is to provide an accurate analysis of terms describing different types of armour that appear in Persian manuscripts. Further, the article provides the readers with a detailed description of different types of armour so that the old texts can be understood easier. In this article, only the period of the New Persian language is considered. Forty seven Persian manuscripts ranging from the $10^{\text {th }}$ to the $19^{\text {th }}$ centuries C.E.

* Dr. Manouchehr Moshtagh Khorasani. M. Moshtagh Consulting. 60230 Frankfurt a.M. - Telefon: 0049-1726783352 - Email: manouchehr@moshtaghkhorasani.com - Internet: www.moshtaghkhorasani.com - www.arms-andarmor-from-iran.de 
were consulted to set up a reliable linguistic base for the study of different types of arms and armour. These manuscripts include epics such as the $10^{\text {th }}$-century epic Š $\bar{a} h n \bar{a} m e$ [Book of Kings] by Ferdŏsi, antologies such as the $11^{\text {th }}$-century anthology Divān-e Manučehri Dāmqāni [Anthology of Manučehri Dāmqāni] by Manučehri Dāmqāni, the travel accounts such as the $11^{\text {th }}$-century Safarnāme-ye Nāser Xosrŏ [Travel Accounts of Nāser Xosrŏ] by Nāser Xosrŏ, treatises on war and strategy such as the 12-century C.E. manuscript $\bar{A} d \bar{a} b$ al-Harb va alŠojā-e [The Customs of War and Bravery] by Mobārak Šāh Faxr-e Modabbar, heroic stories such as the 15th-century manuscript Zafarnāme by Yazdi, historical manuscripts such as the $17^{\text {th }}$-century manuscript Tārix-e Ālam Ārāye Abbāsi [History of Abbāsi] by Eskandar Beig Torkamān, geography and crafts books such as the $19^{\text {th }}$-century Jogrāfiy $\bar{a}$-ye Esfahān [Geography of Isfahan] by Tahvildār Esfahāni, and period lexicons such as the $19^{\text {th }}$-century lexicon Farhang-e Jahānigiri [The Lexicon of Jahānigiri] by Anjavi Širāzi. It is important to note that with armour only body armour, meaning the armour that protects the body (human and animal), is taken into consideration and not defensive weapons such as shields that could also be used as offensive weapons if the need arose.

Generally, one can divide different types of armour into two major categories: human armour and animal armour (armour for animals carrying the warriors such as horses, elephants, and camels). ${ }^{1}$ The article first deals with the human armour and its different types as presented

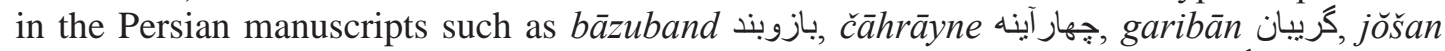

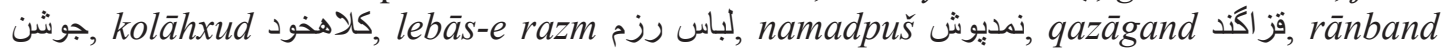

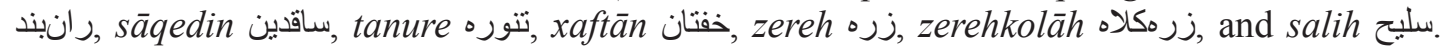
The second part of the article deals with different types of animal armour such as ayne

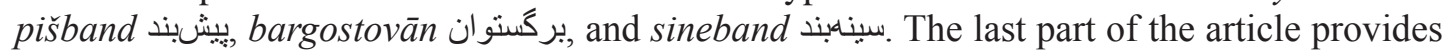
a conclusion.

\section{HUMAN ARMOUR}

Human armour found in the Persian manuscripts can be classified into the following cat-

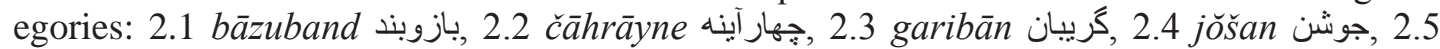

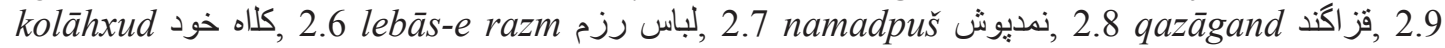

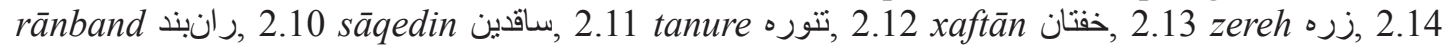

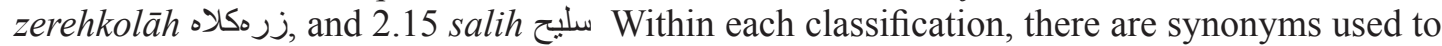
describe the same type of armour and also varieties of that armour. These will be explained in the following. The general term for armour maker is zarrād زراد, see the 12-century C.E. manuscript $\bar{A} d \bar{a} b$ al-Harb va al-Šojā-e (Mobārak Šāh Faxr-e Modabbar, 1967/1346:423) and an arsenal or armoury was called zarrādxāne زرادخانه, see the 11 $11^{\text {th }}$-century anthology Divān-e Manučehri Dāmqāni (Manučehri Dāmqāni, 1984/1363:22). ${ }^{1}$

\subsection{BĀZUBAND بازوبند}

A pair of $b \bar{a} z u b a n d$ بازوبند was used in Iran for protecting the forearms during combat. A bāzuband بازوبند has a main steel plate covering the whole forearm, normally with one or two

1 For the usage of the term zarrādxāne زرادخانه in other Persian manuscripts, see the $12^{\text {th }}$-century manuscript $\bar{A} d \bar{a} b$ al-Harb va al-Šojā-e (Mobārak Šāh Faxr-e Modabbar, 1967/1346:20), the 13 ${ }^{\text {th }}$-century anthology Masnavi Ma'navi (Molavi, 2006/1385:35), the 15th-century manuscript Zafarnāme (Yazdi, 1957/1336a:297), the 14th-century manuscript Tārix-e Firuzšāhi (Afif, 2007/1385:338), and the 15th-century manuscript Dārābnāme (Beiqami, 2002/1381:351; vol.2). 
smaller plates to encircle and close around the wrist, and a textile gauntlet reinforced with mail for protecting the hands (see Kobylinsky, 2000:69). There are two ways of holding the steel plates of bāzuband بازوبند together: either they are held together by mail or by a hinge with a pin (see Kobylinsky, 2000:69). Persian manuscripts such as the Safavid-period manuscript Dāstān Hosseyn Kord-e Šabestari (Dāstān Hosseyn Kord-e Šabestari, 2003/1382:168), the manuscript Romuz-e Hamze recollected in 15 ${ }^{\text {th }}$-century (1940/1359 Hegira: 703), and Širuye Nāmdār (2005/1384:328) report on the usage of this type of armour. Synonyms for the term bāzuband ساعد بند (see the manuscript Eskandarnāme by Hakim, unspecified date: 551 that is based on $12^{\text {th }}$-century tales and recollected in the $17^{\text {th }}$ century $)^{2}$, sa 'edin ساعدين (see the $11^{\text {th }}$-century manuscript Samak Ayyār , al-Kāteb al-Rajāni, 2004/1383:391)33, ساقه (see the 14 $14^{\text {th }}$ century manuscript Tärix-e Sistān, 1992/1381:434)4. Persian manuscripts sometimes describe the decorations used on armguards such as the expressions sāedband-e morassa' ساعد بند مرصع (bejeweled armguard) (see the 19th-century manuscript Rostam al Tavārix, Āsef, 2003/1382:415), sā'edin zarandud ساعدينزر اندود (gilded armguard) (see the 15th-century manuscript Dārābnāme, Beiqami, 2002/1381:602; vol.1), and sāedin zarrin ساعدين زرين (lit. golden armguard; an armguard decorated with gold-inlaying or overlaying) (see the $14^{\text {th }}$-cenury manuscript Majma' al-Ansāb, Šabānkāre'i, 2002/1381:278). ${ }^{5}$

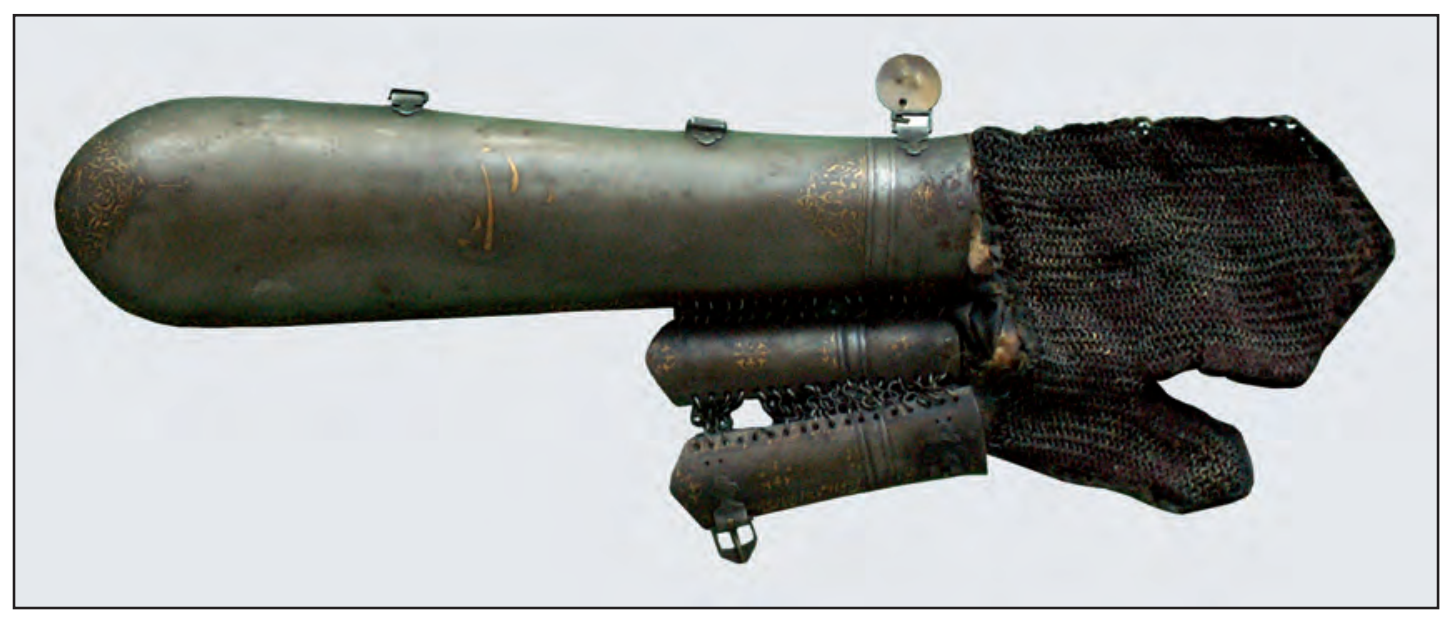

Figure 1. A bāzuband بازوبند made of crucible steel plates attributed to the Safavid period (1502-1722 C.E.) from the Military Museum of Tehran (Courtesy of the Military Museum of Tehran).

2 For the usage of the term sāedband ساعد بند in other manuscripts see Romuz-e Hamze, (1940/1359 Hegira:52) recollected in $15^{\text {th }}$-century, and the $19^{\text {th }}$-century manuscript Rostam al Tavārix, Āsef, 2003/1382:78). This term is also spelt as دنبدعاص, see the manuscript Romuz-e Hamze (1940/1359 Hegira:380).

3 For the usage of the term sā'edin ساعدين in other Persian manuscripts, see Dārābnāme-ye Tarsusi (Tarsusi, 1977/2536;360, vol. 1) that is based on old Pahlavi texts, the 12-century manuscript Ādāb al-Harb va al-Šojā-e (Mobārak Šāh Faxr-e Modabbar, 1967/1346:147), and the 15th-century manuscript Dārābnāme (Beiqami, 2002/1381:293; vol.1).

4 Note that this term is also used as shin protector.

5 For examples of Persian bāzuband بازوبند that are kept in Iranian museums see Moshtagh Khorasani (2006:684, cat. 380 and cat. $381 ; 685$, cat. 382). 


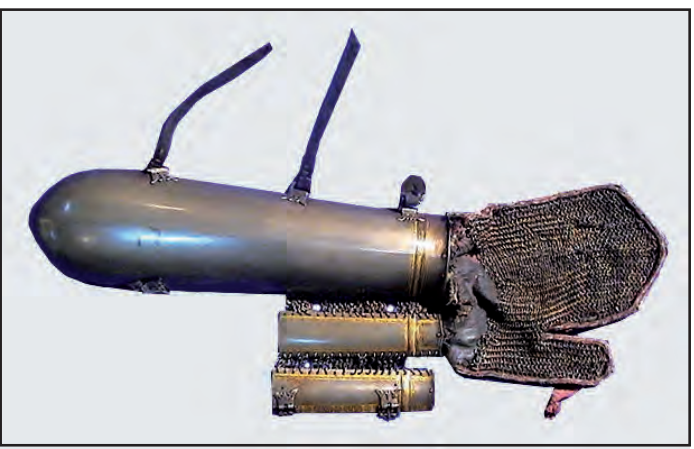

Figure 2. Another bāzuband بازوبند made of crucible steel plates attributed to the Safavid period (15021722 C.E.) from the Military Museum of Tehran (Courtesy of the Military Museum of Tehran).

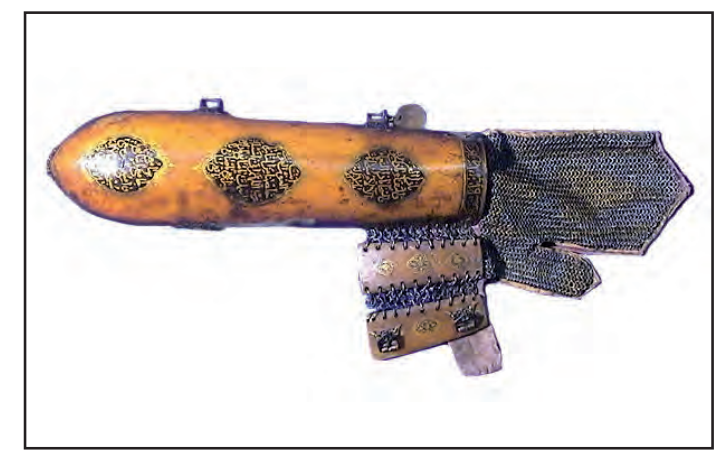

Figure 3. A bāzuband بازوبند made of rhinoceros hide plates attributed to the Zand period (17501794 C.E.) from the Military Museum of Tehran (Courtesy of the Military Museum of Tehran).

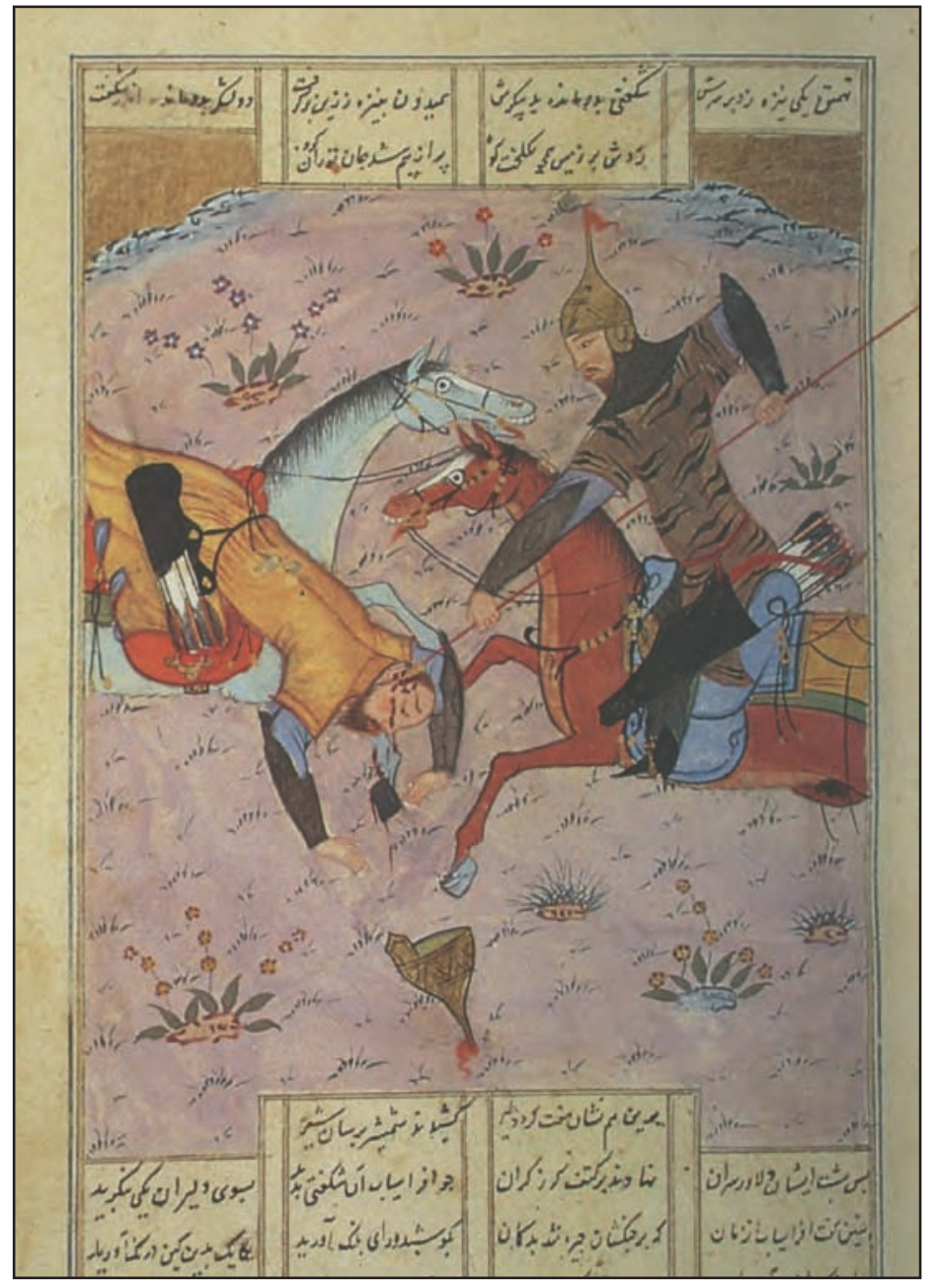

Figure 4. A miniature from a $15^{\text {th }}$-century manuscript of the Šăhnāme shows Rostam fighting Alkus the Turanian champion (Courtesy of Malek Library). 


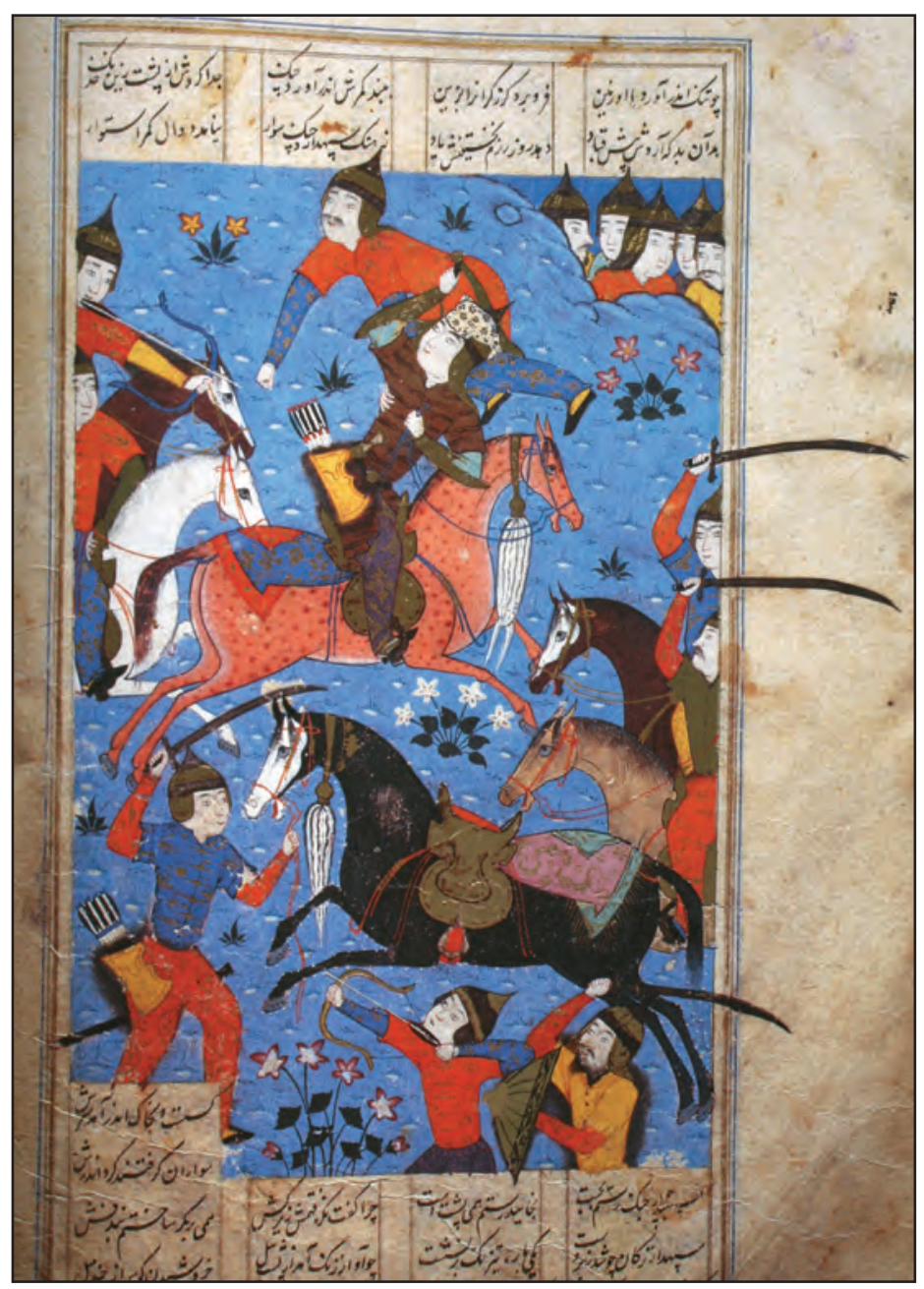

Figure 5. A miniature from a $16^{\text {th }}$-century manuscript of the Šăhnāme shows Rostam fighting the Turks (Courtesy of Sepahsālār Library).

\section{2 ČĀHRĀYNE جهار آينه}

The armour čāhrāyne جهار آينه means literally «four mirrors». It is a a type of armour that consisted of four steel plates, two for protecting the chest and back areas (breast- and backplates) and two for protecting the sides (side plates) (see Grancsay, 1957:245). A single steel/ iron plate serving as a piece of čāhrāyne جهار آينه armour was called âyne آينه (see the Digital Lexicon of Dehxodā). The front plate was called sineband سينهبند (see the manuscript Romuz-e Hamze, 1940/1359 Hegira recollected in $15^{\mathrm{th}}$-century). For the expression sineband-e fulād سينهبند فو لاد (front plate made of steel) see Šăhnāme-ye Nāderi (Nāderi, 1968/1346:54). The steel plates are attached using leather straps, buckles and clasps (see Zeller and Rohrer, 1955:35). The side plates were called baqalband بغلبند (see the Safavid-period manuscript Dāstān Hosseyn Kord-e Šabestari, 2003/1382:30) or baqaltāq بغلظاق or baqaltāq بغلتاق (see the $13^{\text {th }}$-century anthology Bustān, Sa'di, 2005/1383:235, the 12-century manuscript Ādāb al-Harb va 
al-Šojā-e, Mobārak Šāh Faxr-e Modabbar, 1967/1346:467), and the 13 ${ }^{\text {th }}$-century anthology Masnavi Ma'navi (Molavi, 2006/1385:368). At times Persian manuscripts also define where a piece of čăhrāyne جهار آينه armour was made such as the expression ayyne-ye čini آينه (the steel mirror/plate from China/Turkestan [serving as a piece of armour]) (Dārābnāme-ye Tarsusi based on old Pahlavi texts, Tarsusi, 1977/2536, vol. 1). Warriors armed with a čăhrāyne جهار آينه Jāmi, 2001/1379:257). There are some types of čāhrāyne جهار آينه with no leather straps; in this case the plates were pinned together (like hinges), forming a more rigid construction. In some types of čāhrâyne جهار آينه the front plate is made of two pieces, so the armour could be folded like a jacket (see Kobylinsky (2000:68). There are different methods of decoration on steel plates, gold and silver in- and overlays, chiseling and engraving (Kobylinsky, 2000:68). In later models made for the tourist market in the $19^{\text {th }}$ century the decorations were etched onto

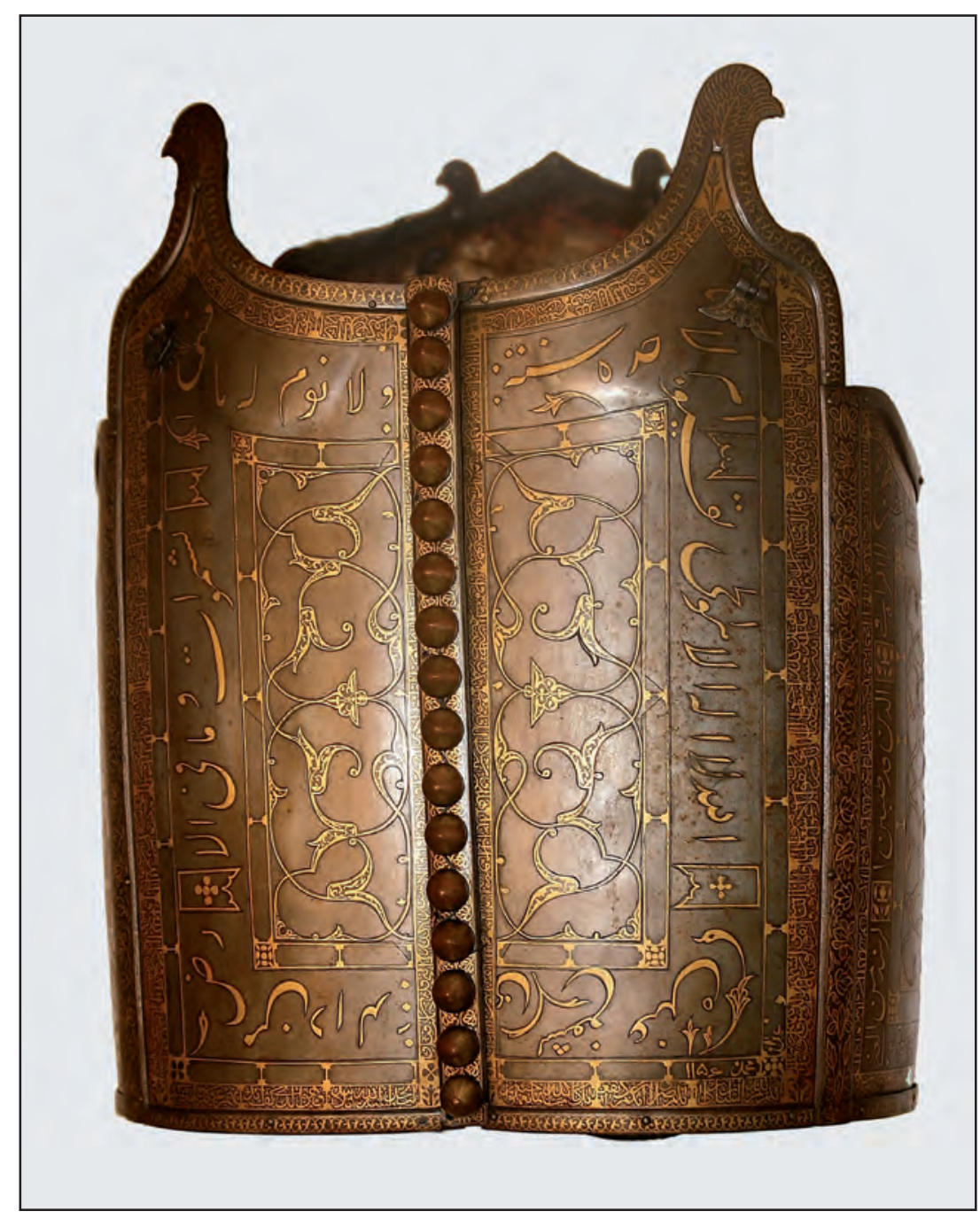

Figure 6. A čāhrāyne made of crucible steel plates with gold-overlaid inscriptions attributed to the Safavid period (1502-1722 C.E.) from the Military Museum of Tehran (Courtesy of the Military Museum of Tehran). 
the steel surface. The armour čāhrāyne جهار آينه was usually worn on top of the zereh زبره (mail armour). At times the Persian manuscripts reveal the material a čāhrāyne جهار آينه was made

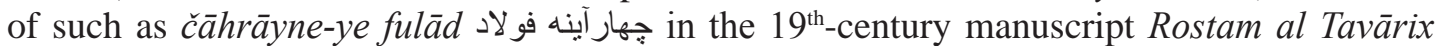
(Āsef, 2003/1382:39). The craftsman who makes a čāhrāyne جهار آينه was called a čāhrāynes $\bar{a} z$ see Jogrāfiyā-ye Esfahān (Tahvildār Esfahāni, 1964/1342:109). ${ }^{6}$

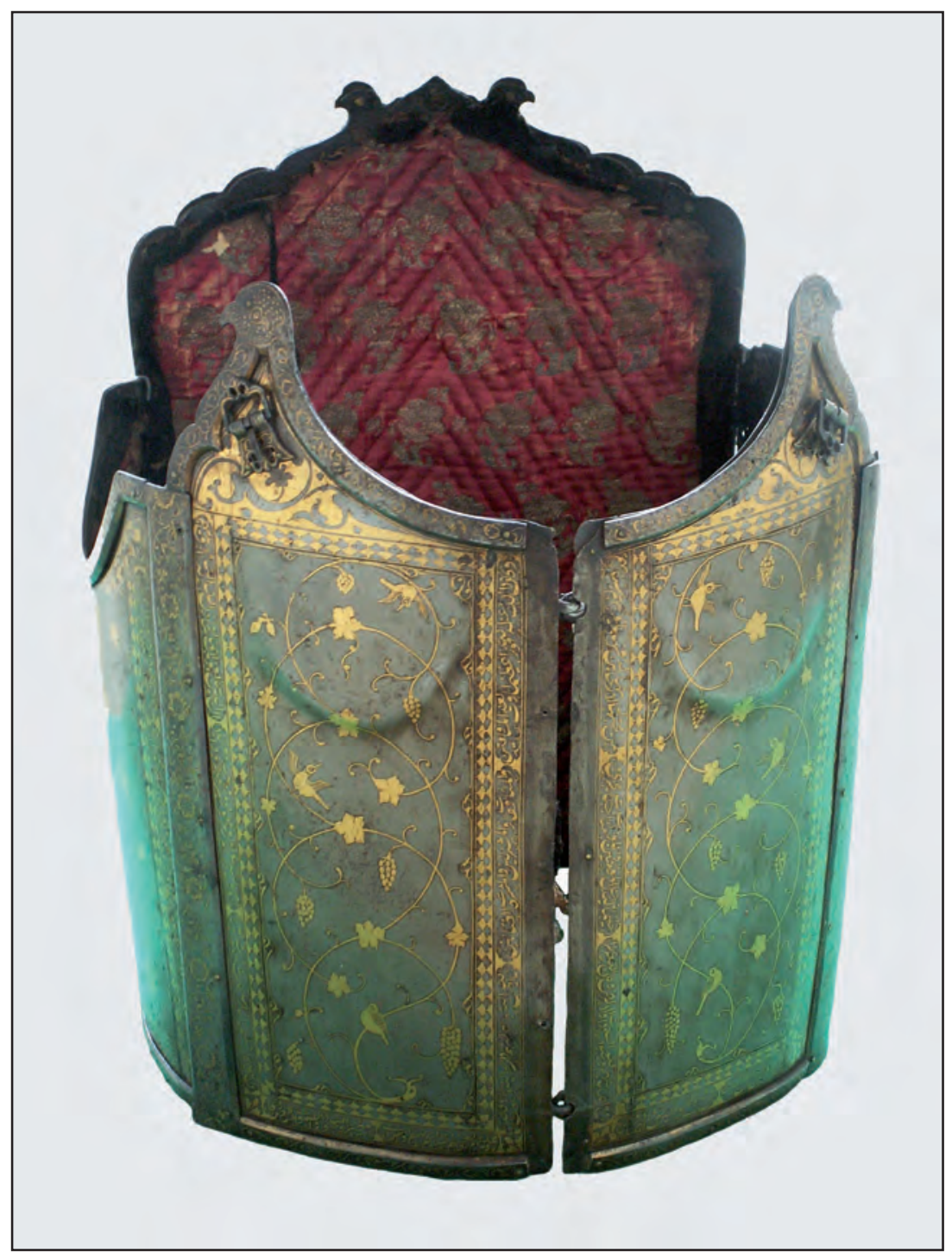

Figure 7. Another čăhrāyne made of crucible steel plates with gold-overlaid inscriptions attributed to the Safavid period (1502-1722 C.E.) from the Military Museum of Tehran (Courtesy of the Military Museum of Tehran).

6 For the usage of the term čāhrāyne جهار آينه in Persian manuscripts see the manuscript Eskandarnāme (Hakim, unspecified date:557) that is based on $12^{\text {th }}$-century tales and recollected in the $17^{\text {th }}$ century and the manuscript Romuz-e

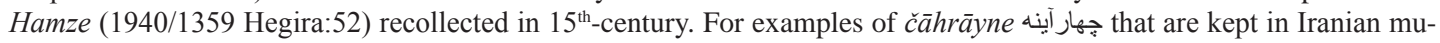
seums see Moshtagh Khorasani (2006:701-715, cat. 396-406). 


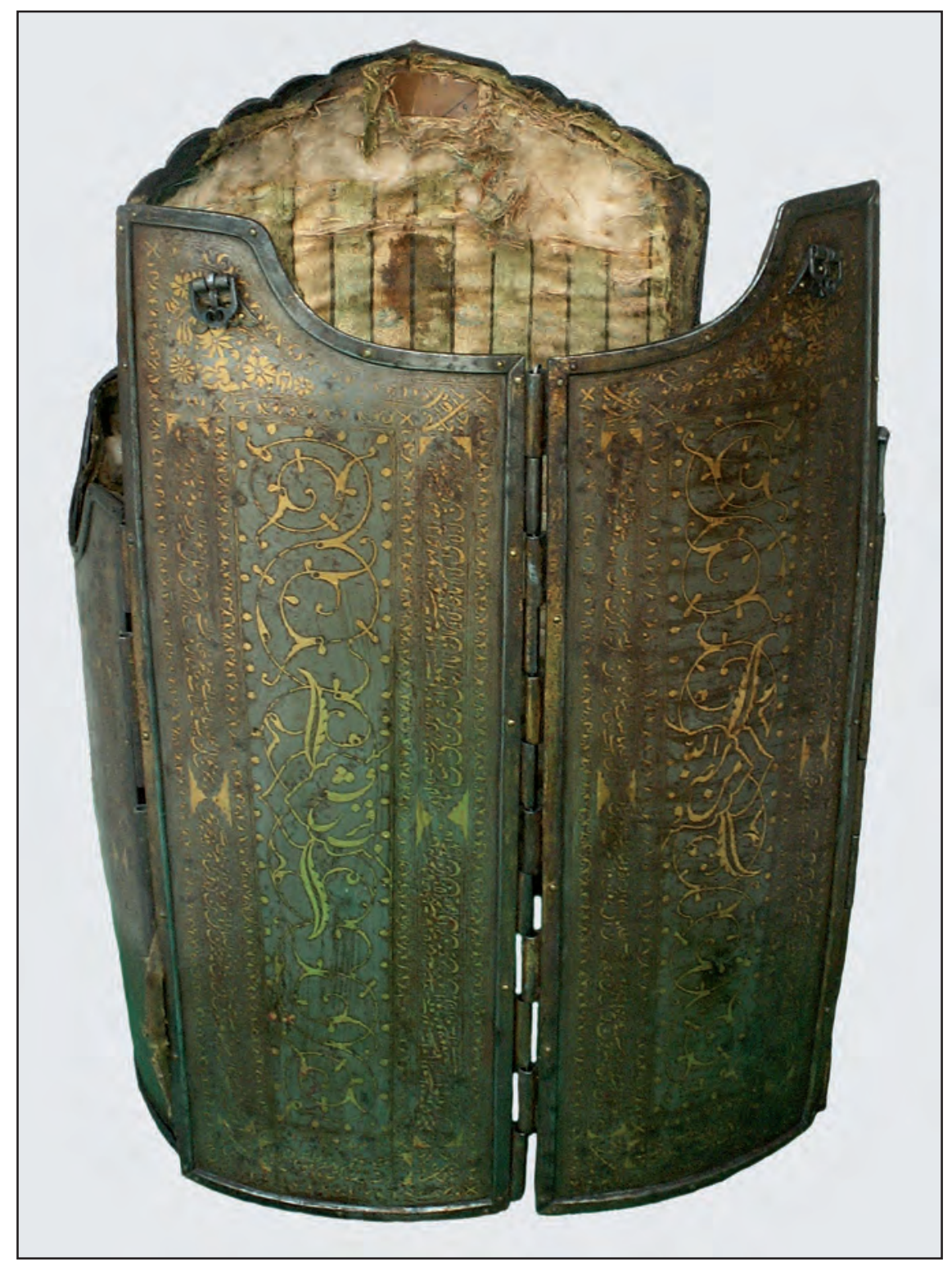

Figure 8. Another čāhrāyne made of crucible steel plates with gold-overlaid inscriptions attributed to the Safavid period (1502-1722 C.E.) from the Military Museum of Bandar Anzali (Courtesy of the Military Museum of Bandar Anzali). 


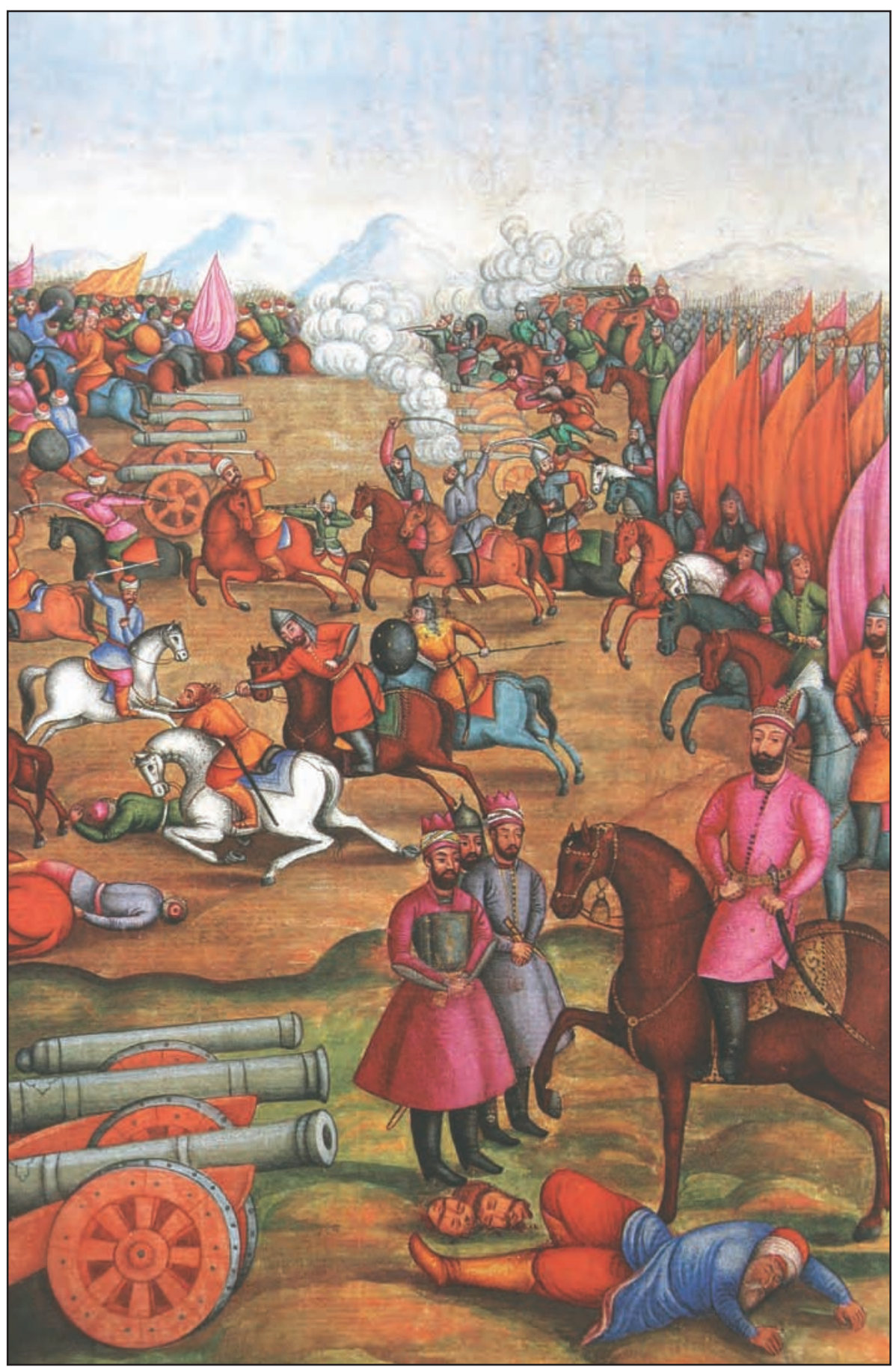

Figure 9. A miniature from the manuscript Tārix-e Jahāngošāy-e Nāderi [The History of the World Conquest of Nāder] shows the campaign between Nāder and Abdollāh Pāšā, the Ottoman general. The Persians have defeated the Ottoman army and the corpse of the Ottoman general is lying on the ground at the feet of Nāder's horse. Three men are standing in front of Nāder Šāh. Note the man standing in the front is wearing a $\check{c} \bar{a} h r a \bar{a} y n e$ similar to the examples shown in pictures 6-8. The manuscript was finished in 1757 C.E. (Courtesy of Abdolali Adib Barumand). 


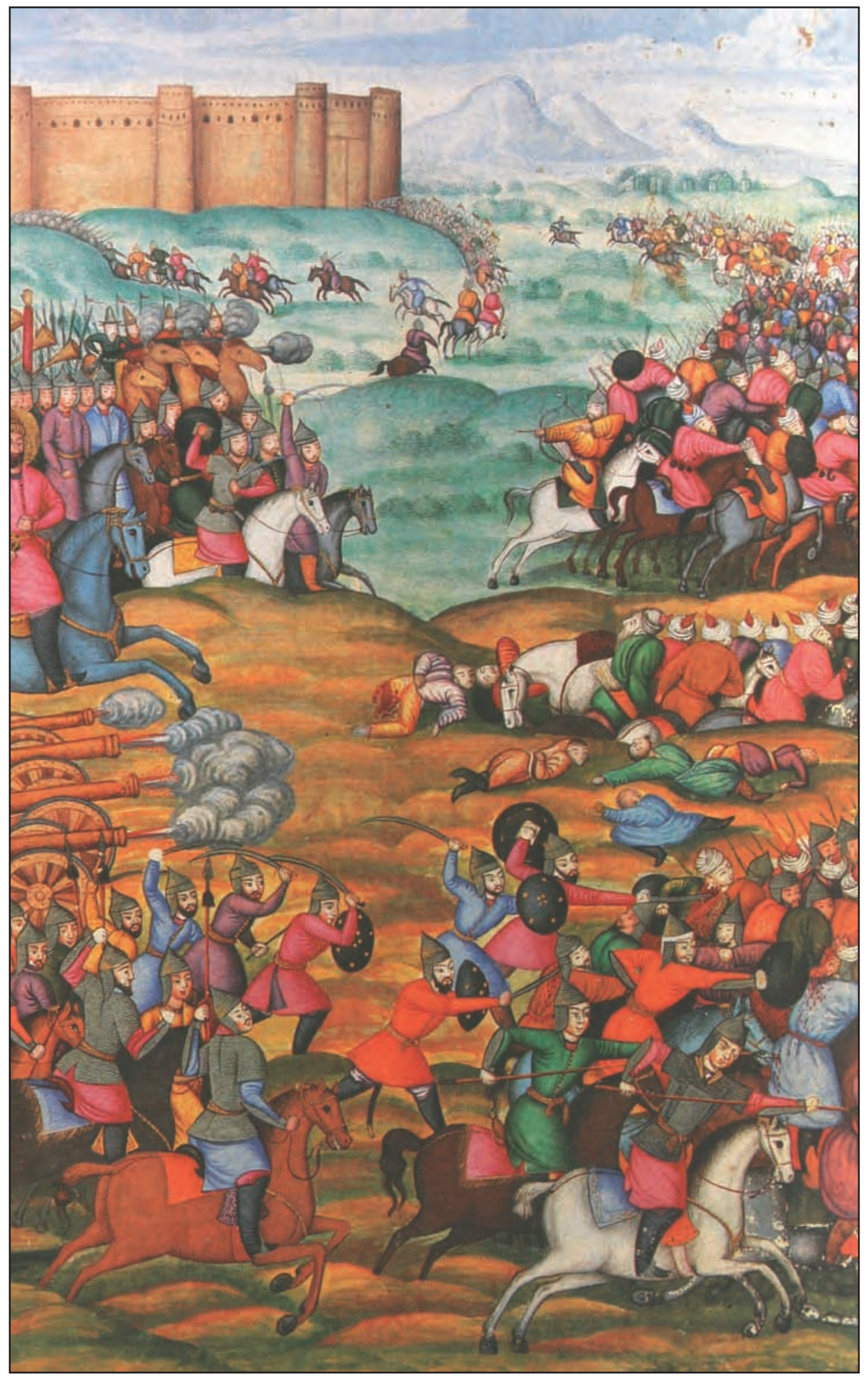

Figure 10. Another miniature from the manuscript Tārix-e Jahāngošāy-e Nāderi [The History of the World Conquest of Nāder] shows a warrior armed with a čăhrāyne and mail armour fighting on the right side of the picture on the bottom. 


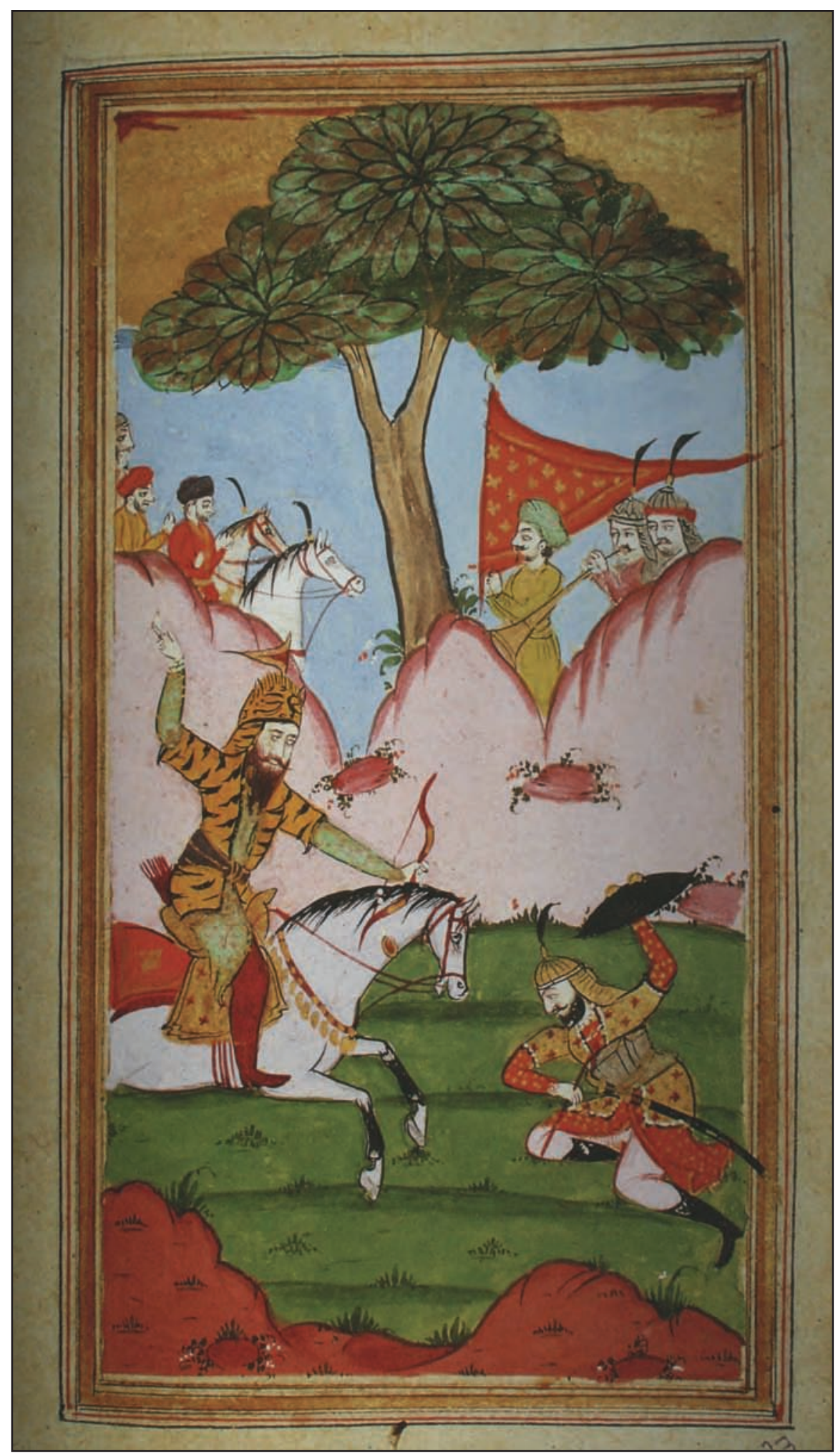

Figure 11. A miniature from an $18^{\text {th }}$-century manuscript of the Šăhnāme shows Rostam on the battlefield (Courtesy of National Library of Iran). 


\section{كريبان GARIBĀN}

It is a type of mail armour that protected the neck but also provided extra protection for the upper breast. The technical term for this piece of armour in English is «standard». The term garibān كريبان is mentioned in the Persian manuscript Eskandarnāme (Hakim, unspecified date:267) that is based on $12^{\text {th }}$-century tales and recollected in the $17^{\text {th }}$ century The roots of the term go back to the Middle Persian/Pahlavi term garìvpān (for the Middle Persian term see Farahvaši, 2002a/1381:525). At times, Presian manuscripts define specifically that garibān كريبان was part of the mail armour such as garibān-e zereh كريبان زره (standard of the mail armour) in the the Safavid-period manuscript Dāstān-e Hosseyn Kord-e Šabestari (Dāstān-e Hosseyn Kord-e Šabestari, 2003/1382:56).

\subsection{JǑŠAN جوشن}

This is a type of armour that is often mentioned in Persian manuscripts. ${ }^{7}$ According to the Digital Lexicon of Dehxodā, jǒšan جوشن is a type of mail-and-plate armour and is similar to tanure insofar as both are made from mail and iron/steel plates; however, the iron/steel

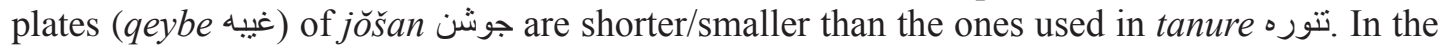
manuscript Dārābnāme-ye Tarsusi based on old Pahlavi texts (Tarsusi, 1977/2536:121, vol. 2), the expression jŏšan-e xord qeybe جوشن خردغيه a jö̌šan جوشن armour with small iron/steel plates) is used supporting the statement by Dehxodā. The 15th-century manuscript Dārābnāme

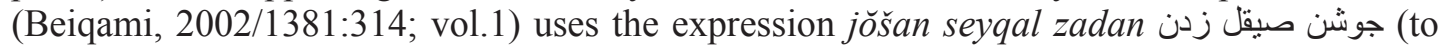
polish زö̌šan جوشن armour), indicating that jŏšan armour was indeed made of metal. The Dārābnāme-ye Tarsusi based on old Pahlavi texts (Tarsusi, 1977/2536:45, vol. 1) uses the term jŏšan-e mozarrad جوشن مزرد (jöšan armour with mail rings) supporting the assumption that $j \check{j o s ̌ a n}$ armour indeed consisted of mail rings as well. Dehxodā also offers the term jŏšan-e diavudi جوشن داودى (literally a jǒšan armour attributed to the Prophet Dāvud; a jŏšan

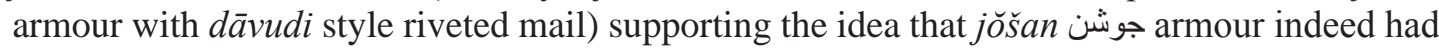

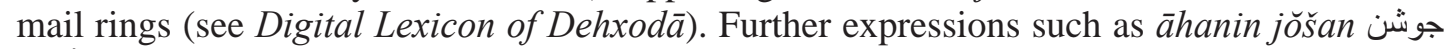
(jŏšan armour made of iron) ${ }^{9}$, and jǒšan-e fulād (jŏšan armour made of steel) ${ }^{10}$ also indicate that the armour had iron and steel parts/ plates in it. The term band-e jŏšan بند جوشن جون was used to refer to the straps that tighten the jŏšan (strap/belt of the armour) (Šăhnāme, Ferdŏsi, 1995/1384:1378):

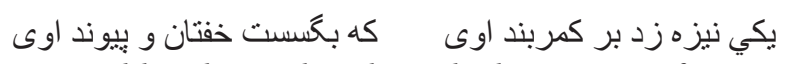

yeki neyze zad bar kamarband uy ke begosast xaftān va peyvand uy

He struck him on the belt with his spear and tore his armour padding and the armour belts.

7 For the usage of jŏšan جوشن in the Persian manuscripts see the $10^{\text {th }}$-century anthology Divān-e Rudaki Samarqandi (Rudaki, 2004/1382:17), the 10 $0^{\text {th }}$-century epic Šāhnāme (Ferdŏsi, 1995/1384:450), the $10^{\text {th }}$-century epic Goštāsbnāme (Daqiqi Tusi, 1994/1373:80), the $11^{\text {th }}$-century epic Garšāsbnāme (Asadi Tusi, 1938:1317:60), the $11^{\text {th }}$-century anthol-

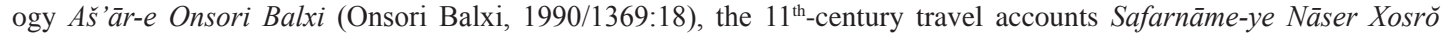

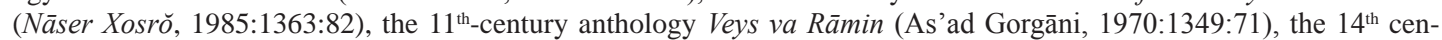
tury manuscript Tārix-e Sistān (1992/1381:434), the 17 ${ }^{\text {th }}$-century anthologyTazakore-ye Nasrābādi (Nasrābādi Esfahāni, 1941/1317:466), and the 18 ${ }^{\text {th }}$-century manuscript Ālam Ārāye Nāderi (Marvi Vazir Marv, 1985/1374:117).

8 See the $19^{\text {th }}$-century anthology Šahanšahnāme (Fathali Xān Sabā, 142).

9 See the 11 ${ }^{\text {th }}$-century manuscript Samak Ayyār (al-Kāteb al-Rajāni, 2004/1383:109).

10 See the 13th-century anthology Qate'àt (Sa'di, 2005/1383:707).

11 See the $10^{\text {th }}$-century epic Šăhnāme (Ferdǒsi, 1995/1384:212). 
In line with Iranian sources, Kobylinsky (2000:68) distinguishes between jǒšan جونش and

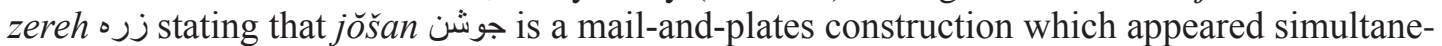
ously in Iran, Turkey, and north India. Kobylinsky (2000:68) states that in Iran, jošsan جوشن was in the shape of jackets or coats from steel mail with two, four, or eight steel plates arranged in two rows, with a buckle in front, and three or five rows of small tiles on the back; these were arranged similarly to roof tiles. Some jǒšan جوشن carry the small tiling on the front. Kobylinsky (2000:68) further stresses that it is very difficult to determine the origin of jǒs̆an since Iranian and Indian pieces are very similar. According to Kobylinsky (2000:68) zereh $\circ j$ jstands for «mail» and there were many types of it in Iran. Interestingly, this is in line with the descriptions given in Persian lexicons.

Quoting the lexicon Annanderāj آنندر اج, the Digital Lexicon of Dehxodā states that jŏšan

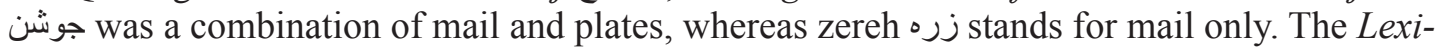
con of Borhān confirms that zereh j j consists of different rings to offer protection for the

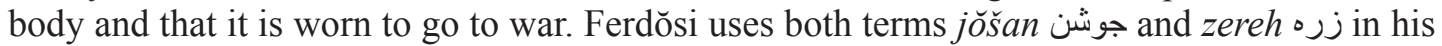
$10^{\text {th }}$-century epic Šăhnāme. Both are used in the $14^{\text {th }}$ century manuscript Tārix-e Sistān as well (see Digital Lexicon of Dehxodā). Regarding different types of armour, Nicolle (1998:15)

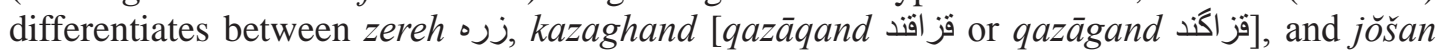
جوشن Similar to the Digital Lexicon of Dehxodā, he states that zereh زره was the traditional mail hauberk. He adds that this body armour remained the main form of body protection. He further opines that qazāqand قز قز qazäghand spread westward from its origins in Iran or Transoxania (in Central Asia) during the $10^{\text {th }}$ century Nicolle (2002:188) also differentiates between jǒšan جونَ (lamellar cuirass in his explanation), zereh زره (mail hauberk) and iron tanur تنور. In Nicolle`s terms, the latter term is used to refer to more ancient Sassanian armour. However, one should note that tanur تنور was not only used during the Sassanian period as an armour type called tanure تنور was also in use in later periods as was a type of armour made of mail and plates. Nicolle suggests that he based his statements on the reports by al-Thaàlini writing in the late tenth century. But one should note that jǒšan ar never referred to lamellar armour. It might have referred to some type of leather armour - but not lamellar - and, it later refers to a combination of mail and plates. In Europe, this covered mail was initially called a jazerant and was later known as a gestron.

According to Nicolle (2002:180), jazerant or jazrain stems from the Persian word kazaqand and means a mail shirt (haubergeon) with integral padding plus a fabric-covered exterior. Interestingly, Nicolle (1998:15) considers jǒšan جوشن to be a lamellar cuirass that was adopted from the east where it had been most common. Nicolle explains that it could be made of iron, horn, or hardened leather, and was usually laced with gut and buckled at the side of the body. He adds that jŏšan جوشن from Iran were heavier than those from Byzantium (Nicolle, 1998:15). Based on the epic Šăhnamme which was written in the $10^{\text {th }}$ century, Nicolle (2002:189) states that the heroes of the epic wear mail armour and lamellar jǒšan جوشن cuirasses, but does not provide any specific reference to indicate whether these two terms were described in detail regarding their construction in the $10^{\text {th }}$-century epic Šăhnāme. However, Nicolle (2002:192) admits that although the $\breve{S} \bar{a} h n \bar{a} m e$ provides additional details regarding the construction of a a جوشن and makes references to its leather straps or fastening, one gets the impression that jŏšan جوشن was a cuirass made of iron rather than hardened leather elements. In the Šāhnāme, the leather straps are called band-e jŏšan بند جوشن, (Ferdŏsi, 1995/1384:212). The expression جوشن آهن (armour made of iron) used in the 11 $11^{\text {th }}$-century manuscript Samak Ayyār جوشن (al-Kāteb al-Rajāni, 2004/1383:109) shows that jǒšan جوشن or at least a type of jǒšn was made of iron. Additionally, the combination jŏšan-i zarrin جوشني زرين (lit. golden jŏšan 
armour; a jǒšan armour decorated with gold-inlaying or overlaying) ${ }^{12}$ shows that jǒšan جون would have been made from a certain type of metal to allow gold-inlaying. In the same line of argumenta-

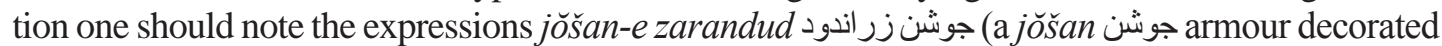

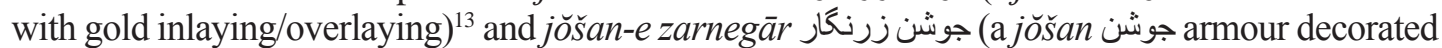
with gold inlaying/overlaying) ${ }^{14}$ indicate that $j \check{\text { ǒsanan }}$ would have been made from a certain type of metal. One should also take into consideration that, based on the Digital Lexicon of Dehxodā, later Iranian sources consider jǒšan جوشن to be a combination of mail and plates and not lamellar armour as shown above. In the $11^{\text {th }}$-century manuscript Samak Ayyār, jŏšan جونش is explained as an armour that was worn over mail armour, see al-Kāteb al-Rajāni (2004/1383:391):

$$
\text { زر هي داودى يوشديد و جوشن بسيار خوب بالاى آن داشدت }
$$

Zereh-i dāvudi pušide va joššn-i besyār xub bālāye an dāšt

He was wearing a riveted mail armour and over that a jŏšan.

In another place in the $11^{\text {th }}$-century manuscript Samak Ayyār the expression halqe-hāye jǒšan حلقهاى جوشن (the rings of jǒšan) is used (al-Kāteb al-Rajāni, 2004/1383:854). The term halqe حلق means «ring» and refers to the rings used in mail armour. Note that the $11^{\text {th }}$-century manuscript Samak Ayyār was written by Faramarz ben Xodādād ben Abdollāh al-Kāteb alRajāni possibly at the end of the $5^{\text {th }}$ century Hegira (the beginning of the $12^{\text {th }}$ century) and is one of the oldest books in Persian literature. Taking the above statement into consideration, it is clear that jošsan جوشن was a type of armour that was worn over mail armour similar to the later čâhrāayne جهار آينه (four mirrors). It could also be that jŏšan جوشن in the example above only refers to the qeybe غييه (metal plates) of the mail-and-plates construction of the armour. Regarding the material of the jǒšan جوشن, Nicolle (2002:191) states that medieval authors such as al-Tabari and al-Tarsusi relate that jŏšan جوشن is of Iranian origin, and that al-Tarsusi gives instructions on how to make jŏšan جوشن of leather. Al-Tarsusi states that to make jŏšan جوشن, one should take camel skins, and soak them in milk and soda to get rid of the hair until the skins are whitened (Nicolle, 2002:203). According to Nicolle (2002:204), al-Tarsusis states that the jö̌san جوشن is then molded from skin in the desired shape. Al-Tarsusi further adds that one should take a glass-full of -- (this word has disappeared; according to Nicolle, it is not clear what material in the manuscript) and pulverise it. The next step involves making a glue of this powder mixed with one equal part of filings/ shavings of isfadariya (according to Nicolle the meaning is unknown), red copper and some crushed emery. Al-Tarsusi explains that this glue is spread over the cut skins up to four times after each layer is dried up, resulting in four layers. He adds that the dried skins can then be varnished, colored or gilded (Nicolle, 2002:204). As mentioned above, in the 11 ${ }^{\text {th }}$-century manuscript Samak Ayyār, al-Kāteb alRajāni (2004/1383:109) refers to jŏšan جوشن as an armour that is made of iron and calls it jŏšan-e ăhan جوشن آهن.

On the other hand, in the $10^{\text {th }}$-century epic Šăhnāme, Ferdǒsi refers to a type of jǒs̆an جوشن ز جرم : بلنح 1995/1384:450). This was obviously a very effective armour as is shown in the following verses:

$$
\text { مر ا با دلاور بسى بود جنى يكى جوشنستش ز جرم يلنى }
$$

Mārā bā delāvar basi bud jang Yeki jǒšansetaš ze čarm-e palang

12 See the $14^{\text {th }}$-cenury manuscriptMajma' al-Ansāb (Šabānkāre'i, 2002/1381:278).

13 See the 15th-century manuscript Dārābnāme (Beiqami, 2002/1381:295; vol.1).

14 See the 15th-century manuscript Dārābnāme (Beiqami, 2002/1381:409; vol.1). 
[I fought against that brave man, who had an armour made of leopard hide, a lot]

$$
\text { سليحم نيامد برو كاركَ بسى آزمودم به كَرز و تبر }
$$

Saliham nayāmad baru kārgar Basi āzmudam be gorz-o tabar

[My weapon did not have an effect on him no matter how much I tried by mace and axe].

In the same light, there was a type of armour called babrbayān ببربيان or babr-e bayān see Loqat-e Fors (Asadi Tusi, 1986/1365:143). Farhang-e Nafisi describes babrbayān a long cloth made of leopard [tiger] hide worn by soldiers and also by Rostam (see Nafisi, 1964/1343:528, vol. 1).

جوشن There are other expressions in Persian manuscripts which indicate that a type of jǒšan

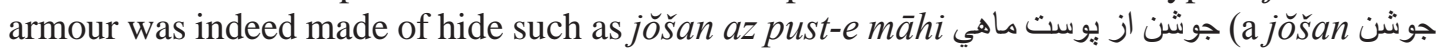

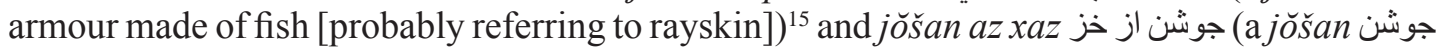
armour made of the hide of a fur-bearing animal). ${ }^{16}$ Taking this account into consideration, it could be that the term jǒšan جوشن went through a semantic shift through the centuries, or it could be that both materials existed in the beginning and later jǒšan جوشن was used to refer to mail-and-plate armour exclusively. In the poems Qate' ât (pieces), Sa'di (2005/1383:707) uses the term jŏšan-e fulād جوشن فو لاد (jošsan armour made of steel). It seems that jǒšan جوشن was made of different types of materials, such as metal and hide. It is not suprising as although the majority of $\bar{c} a \bar{h} h \bar{a} y n e$ جهار آينه were made of steel, there are also examples made of rhino hide (see Moshtagh Khorasani, 2006:712, cat. 403). Things become even more complicated, as in the 12-century manuscript $\bar{A} d \bar{a} b$ al-Harb va al-Šojā-e, it is stated that jŏšan جوشن was worn under the zereh زره (mail armour) (Mobārak Šāh Faxr-e Modabbar, 1967/1346:452):

$$
\text { زر هى يوشيده و جوشنى زير آن بوشيده }
$$

zereh-i pušide va jŏšani zir ān pušide

He was wearing a mail armour and underneath it a jǒšan armour.

Persian manuscripts sometimes reveal the color of a jŏšan جوشن armour such as siyah سيه جوشن (the black armour). ${ }^{17}$ An armour with a rough surface is called jǒšan-e xarpošte or simply xarpošte جوشن خريشته

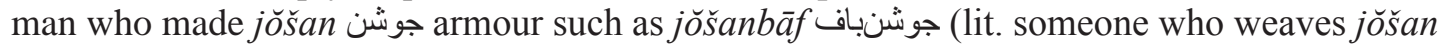

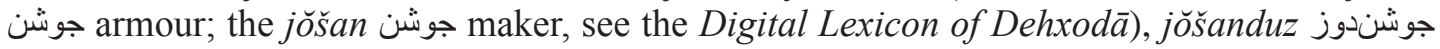

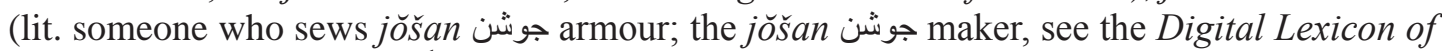
Dehxodāa), and jŏšangar جوشن شوشن armour).

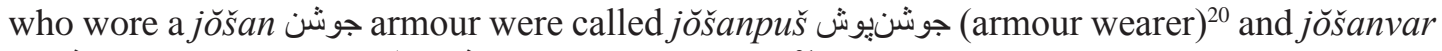
(armour wearer).

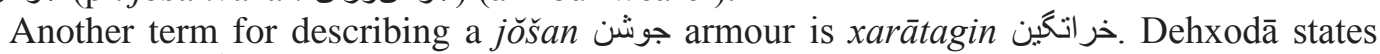

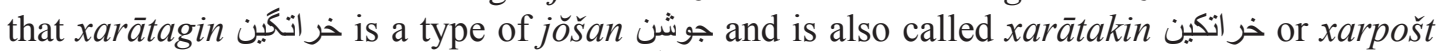
in the 12-century manuscript Ādāb al-Harb va al-Šojā-e (Mobārak Šāh Faxr-e Modabbar, 1967/1346:467) or xarāmkeši خر خركثي or xarātagin (Mobārak Šāh Faxr-e Modabbar, 1967/1346:339). Dorrāa'e دراع is another term that is

\footnotetext{
15 See Dārābnāme-ye Tarsusi (Tarsusi, 1977/2536:73, vol. 1) that is based on old Pahlavi texts.

16 See the $11^{\text {th }}$-century anthology Divān-e Mas 'ud Sa'd Salmān (Sa'd Salmān, 1995/1374:381).

7 See the $19^{\text {th }}$-century athology Šahanšahnāme (Fathali Xān Sabā, 21).

18 See the $11^{\text {th }}$-century anthology Divān-e Manučehri Dāmqāni (Manučehri Dāmqāni, 1984/1363:18)

19 See the $11^{\text {th }}$-century anthology Divān-e Manučehri Dāmqāni (Manučehri Dāmqāni, 1984/1363:76).

20 See the 12-century manuscript $\bar{A} d \bar{a} b$ al-Harb va al-Šojā-e (Mobārak Šāh Faxr-e Modabbar, 1967/1346:249).

21 See the $10^{\text {th }}$-century epic Šāhnāme (Ferdŏsi, 1995/1384:198).
} 


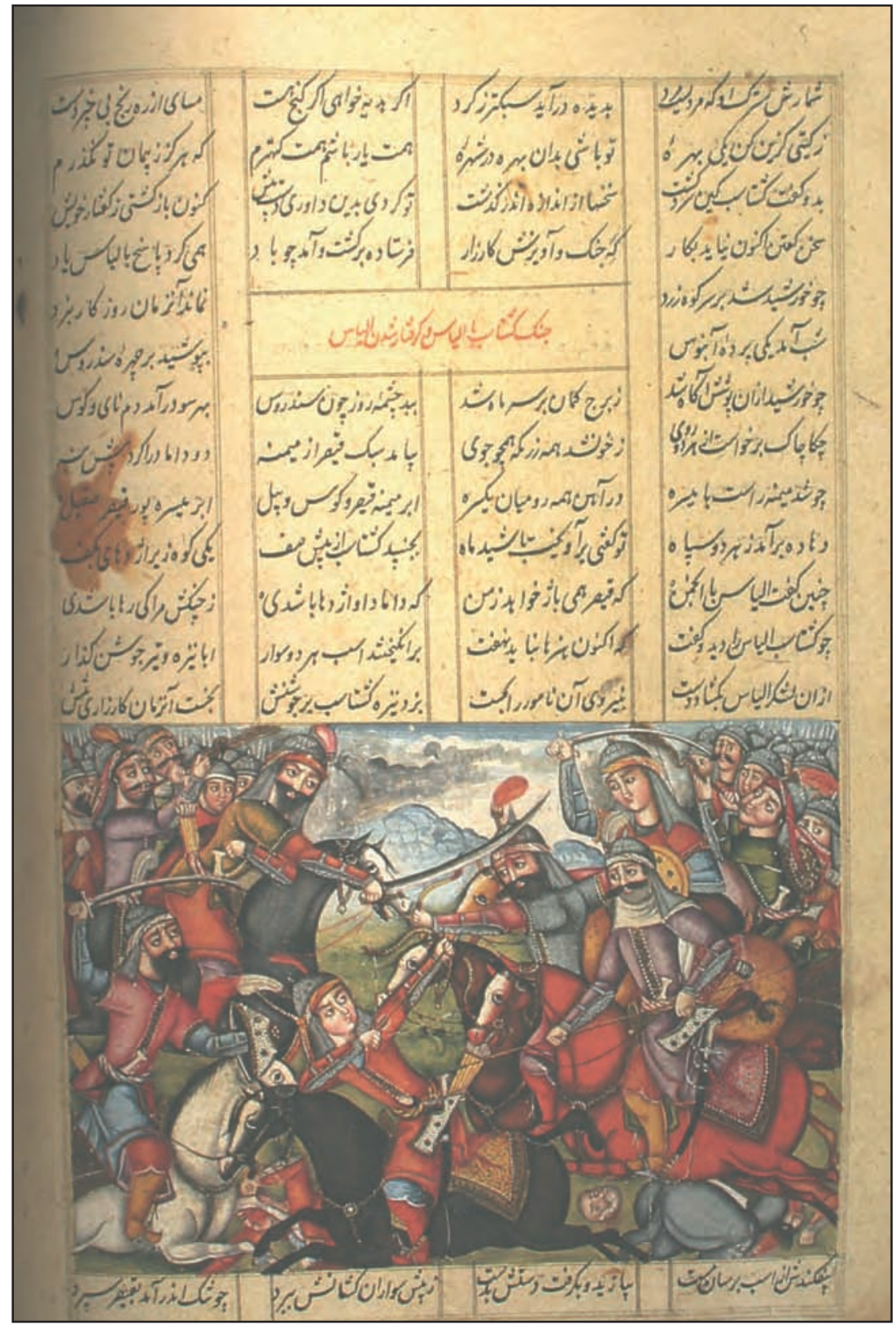

Figure 12. A miniature from a $17^{\text {th }}$-century manuscript of the Šăhnāme shows the battlefield between the army of Gaštāsp with the army of Alyās (Courtesy of the National Library of Iran).

used to describe a jošsan جوشن armour (see the Digital Lexicon of Dehxodā). This is also written

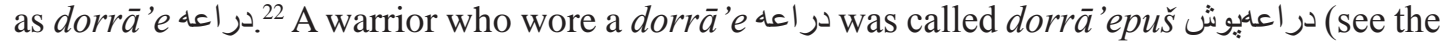
Digital Lexicon of Dehxodā).

22 See the $11^{\text {th }}$-century manuscript Tärix-e Beyhaqi (Beyhaqi, 2004/1383:521) and the $11^{\text {th }}$-century onthology Aš 'är-e Onsori Balxi (Onsori Balxi, 1990/1369:22). 
Another armour that was also worn with mail armour was called jobbe "جبه. ing sentences from the $17^{\text {th }}$-century manuscript Rozat al-Safaviye (Jonābodi, 1999/1378:441) show that jobbe جبهwas worn together with zereh زره (mail armour):

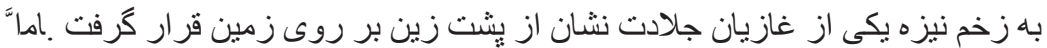

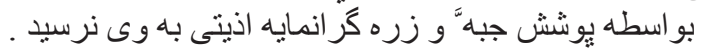

[. . .] be zaxm-e neyze yeki az qāziān jelādat nešan az pošt-e zin bar ruye zamin garār gereft. Amma be vāseteye püššs-e jobbe va zereh gerānmāye aziyatti be vey naresid.

[. . .] with the strike of a spear by one of the brave warriors, he was unsaddled and hit the ground. However, due to the armour (oabbe جبه) and the quality mail armour; he was wearing, he was not injured.

The person who wore a jobbe جبهَ was called jobbe'dār جبهدار (see Farhang-e Nafisi, Nafisi, 1964/1343:1064, vol. 2) and jobbe 'puš جبهوش (see the 15th-century manuscript Zafarnāme, Yazdi, 1957/1336b:69).

\section{كلاه خود KOLĀHXUD}

In Persian manuscripts, the term kolāhxud كلاه خود is used to refer to the helmet used by warriors. ${ }^{24}$ The Iranian helmets from the period following the Mongol Invasion in the $13^{\text {th }}$ century had a round dome ending at the top with either a pointed tuft or a protruding spike (Kobylinsky, 2000:69). These helmets had mail or leather aventails to protect the neck and face. According to Kobylinsky (2000:69), based on the miniatures from the $14^{\text {th }}$ century, helmets from this period were simple with spherical or slightly cone shaped domes with ear protectors in the form of circular plates. These also have aventails in the form of mail. Zeller and Rohrer (1955:36) state that the Iranian helmets are made of steel. The shape of the helmet has remained the same for centuries: a hemispherical bell or cone-shaped. There is a nose protector, damāqak, in the front. There are also cases for holding feathers called jāpari; the feathers that were put into them were called ablaq. Normally, helmets had two plume holders for two

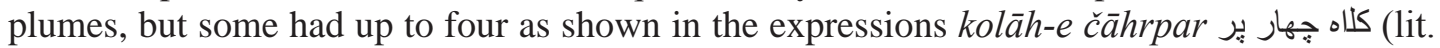
a hat with four plumes/feathers; a helmet with four plumes/feathers ${ }^{25}$ and kolahh-i siyah-e čăhrpar كلاهیى سيه جهار بر (a black helmet with four plumes/feathers). ${ }^{26}$

There is also an aventail made of mail. According to Zoka (1971/1350:191), the Safavid helmets were called either kolāhxud or tāskolāh and were comprised of two parts: the first part was the conical-shaped piece covering the head, which was made of hard steel, and the other was the neck protector made of mail rings protecting the neck. Further, he states that before putting the kolāhxud on the head, a cloth made of felt or silk, comprising of seven layers, was placed on the head for extra protection. This was called araqčin (sweat collector). Some Qajar helmets are decorated with bird wings and heads (see Chodynski, 2000: plates 52; 61). According to Harper (1985:247), these Qajar helmets with birds' wings are made

23 For the usage of the term jobbe "جبه see the $11^{\text {th }}$-century manuscript Târix-e Beyhaqi (Beyhaqi, 2004/1383:521, the 15th-century manuscript Zafarnāme (Yazdi, 1957/1336a:267, 412), the 17 ${ }^{\text {th }}$-century manuscript Rozat al-Safaviye (Jonābodi, 1999/1378:134), and the Safavid-period manuscript Ālam Ârāye Šāh Tahmāsp (1991/1370:59).

24 For example, see the $11^{\text {th }}$-century manuscript Samak Ayyār (al-Kāteb al-Rajāni, 2004/1383:180) and the $19^{\text {th }}$ century manuscript Rostam al Tavārix (Āsef, 2003/1382:191),

25 See the $11^{\text {th }}$-century manuscript Târix-e Beyhaqi (Beyhaqi, 2004/1383:509).

26 See the $11^{\text {th }}$-century epic Garšāsbnāme (Asadi Tusi, 1938:1317:348). 
in the fashion of late Sassanian crowns. There are also expressions that describe the fluted dome (numbers of flutes) of a helmet such as kolāhxud-e čahrpahlu كلاه خود جهاريهلو (helmet

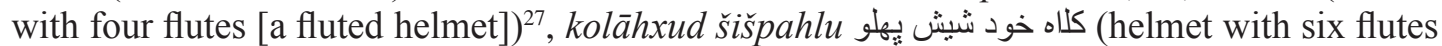
[a fluted helmet]) ${ }^{28}$, kolāhxud-e haštvajh كلاه خود هشت وجد (a helmet with eight flutes [a fluted helmet]) كلاه خود دوازده يُهلو (a helmet with twelve flutes [a fluted

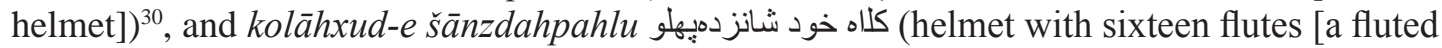

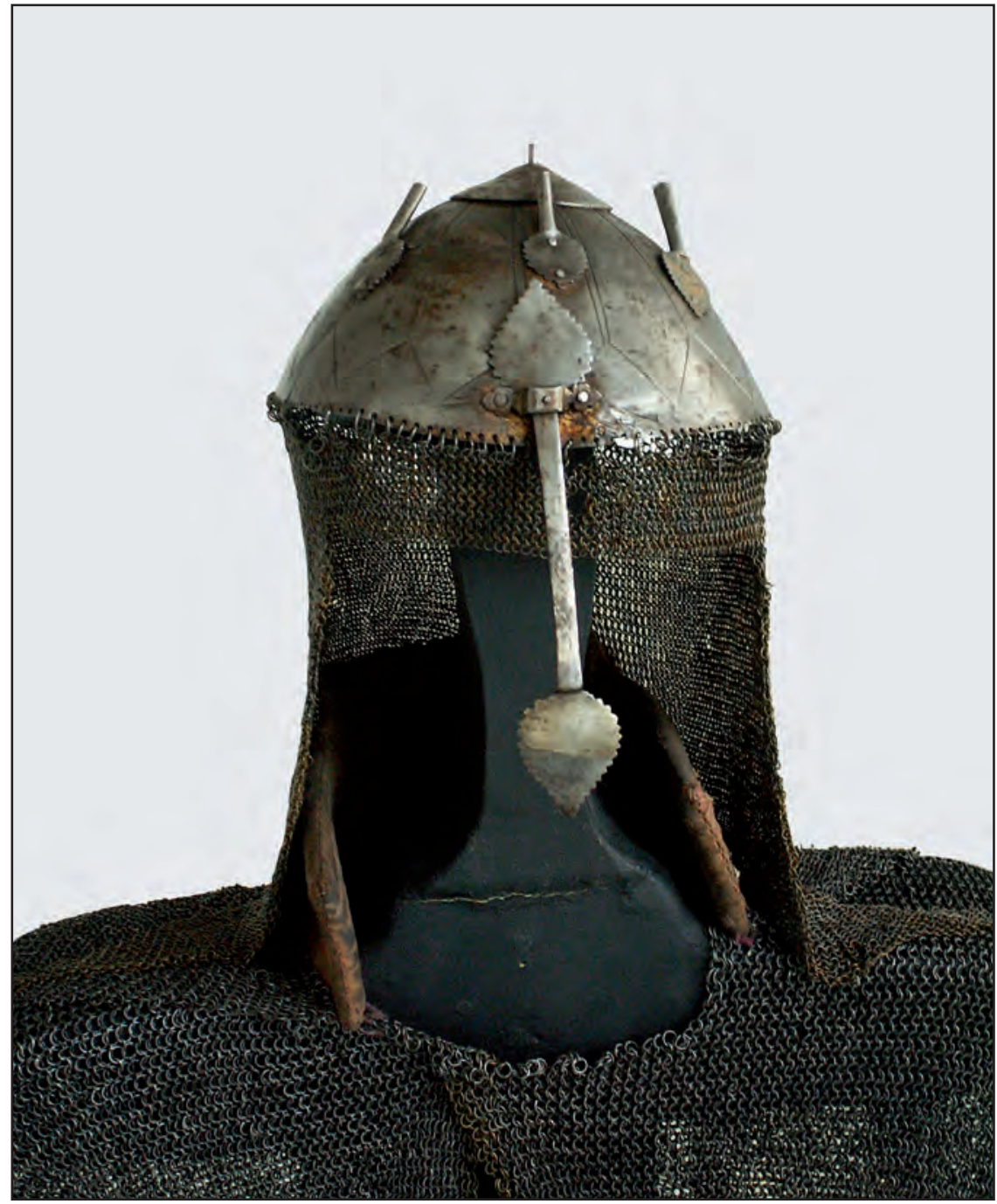

Figure 13. A kolāhxud made of crucible steel attributed to the era of Fath Ali Šāh Qājār (1797-1834 C.E.) with the gold-inlaid inscriptions Al Soltān Fath Ali Šāh Qājār (The ruler Fath Ali Šāh Qājār) on the nose protector (Courtesy of the Military Museum of Tehran).

27 See the 15th-century manuscript Dārābnāme (Beiqami, 2002/1381:277; vol.1).

28 See the $11^{\text {th }}$-century manuscript Samak Ayyār (al-Kāteb al-Rajāni, 2004/1383:423).

29 See the $11^{\text {th }}$-century manuscript Samak Ayyār (al-Kāteb al-Rajāni, 2004/1383:927).

30 See the 15th-century manuscript Dārābnāme (Beiqami, 2002/1381:621; vol.1). 
helmet]). ${ }^{31}$ There are also expressions that indicate gold-inlaying or gilding such as kolāhxud-e

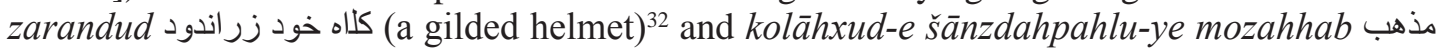
كلاه خود شانزدميهلو (a gilded helmet with sixteen flutes). decorated with jewels such as kolāhxud-e gŏharnegār كلاه خود كو هرنيخار (helmet decorated with jewels). ${ }^{34}$ A craftsman who made helmets was called kolāhxudsāz كلادخودسار. two horns on the top were called kolāh-e došāx كلاه دوشاخ (lit. a hat with two horns, a helmet with two horns). ${ }^{36}$ Sometimes, Persian manuscripts reveal where the steel for making a helmet came from such as the expression kolāh-i ze pulād-e čin كلاهى ز يو لاد جِين (a helmet made of steel from Turkestan/China). ${ }^{37}$

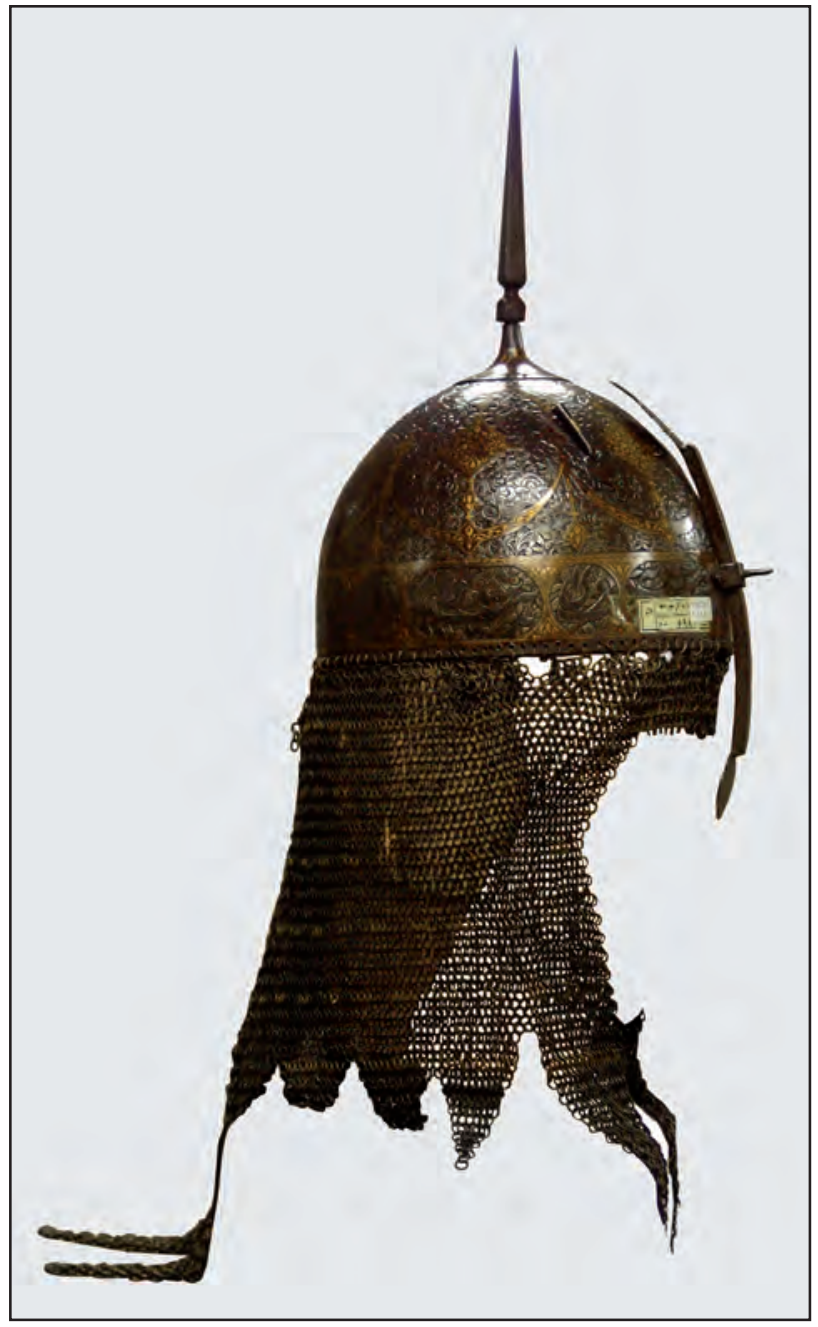

Figure 14: A chiseled and gold-overlaid kolāhxud made of crucible steel attributed to the Qājār period (1794-1925 C.E.) (Courtesy of the Cultural Institute of Bonyād).

\footnotetext{
31 See the 15th-century manuscript Dārābnāme (Beiqami, 2002/1381:603; vol.1).

32 See the 15th-century manuscript Dārābnāme (Beiqami, 2002/1381:628; vol.1).

33 See the 15th-century manuscript Dārābnāme (Beiqami, 2002/1381:626; vol.2).

34 See the $11^{\text {th }}$-century manuscript Samak Ayyār (al-Kāteb al-Rajāni, 2004/1383:816).

35 See the 19 ${ }^{\text {th }}$-century manuscript Jogrāfiyā-ye Esfahān (Tahvildār Esfahāni, 1964/1342:109).

36 See the $11^{\text {th }}$-century manuscript Tärix-e Beyhaqi (Beyhaqi, 2004/1383:79).

37 See the $12^{\text {th }}$-century manuscript Šarafnāme (Nezāmi Ganje'i, 2007/1385a:125).
} 


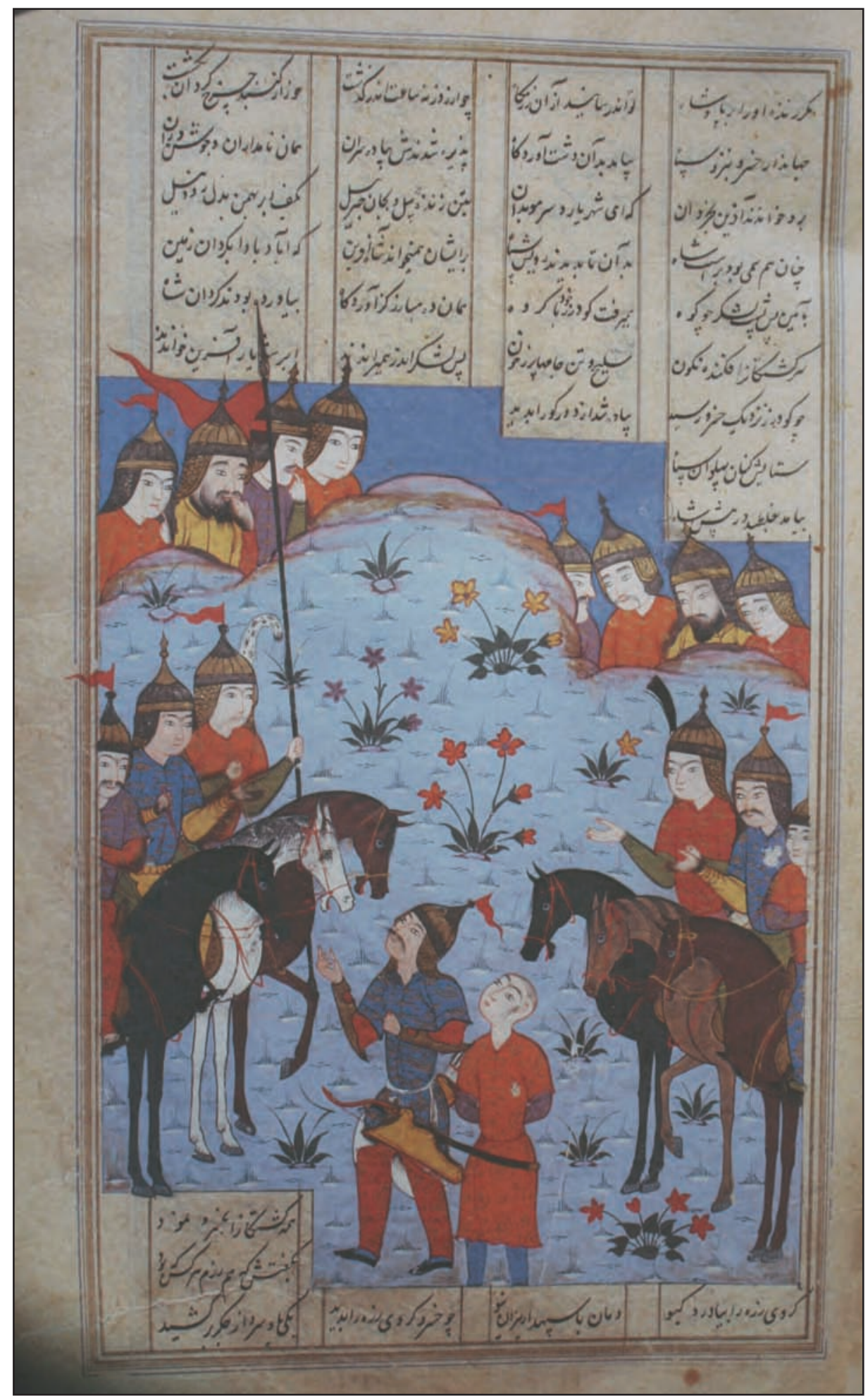

Figure 15. A miniature from a $16^{\text {th }}$-century manuscript of the $\breve{S} \bar{a} h n \bar{a} m e$ shows Keyxosro and the Turanian leaders (Courtesy of Sepahsālār Library). Note the warriors who are wearing fluted helmets. 


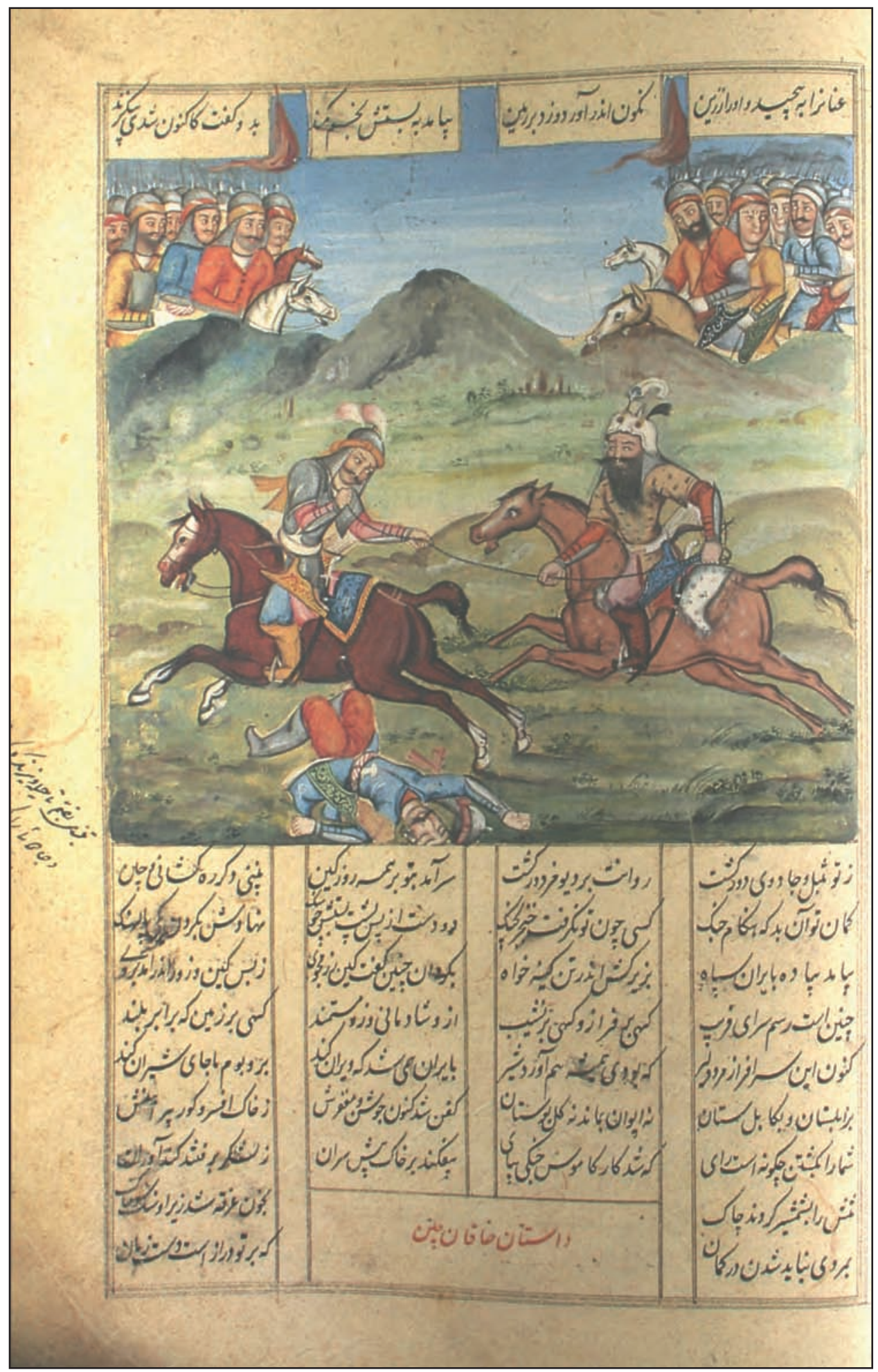

Figure 16. A miniature from a $17^{\text {th }}$-century manuscript of the $\check{S} \bar{a} h n \bar{a} m e$ depicts Rostam fighting Kāmus (Courtesy of the National Library of Iran). Note the warriors who are wearing dome-shaped helmets. 


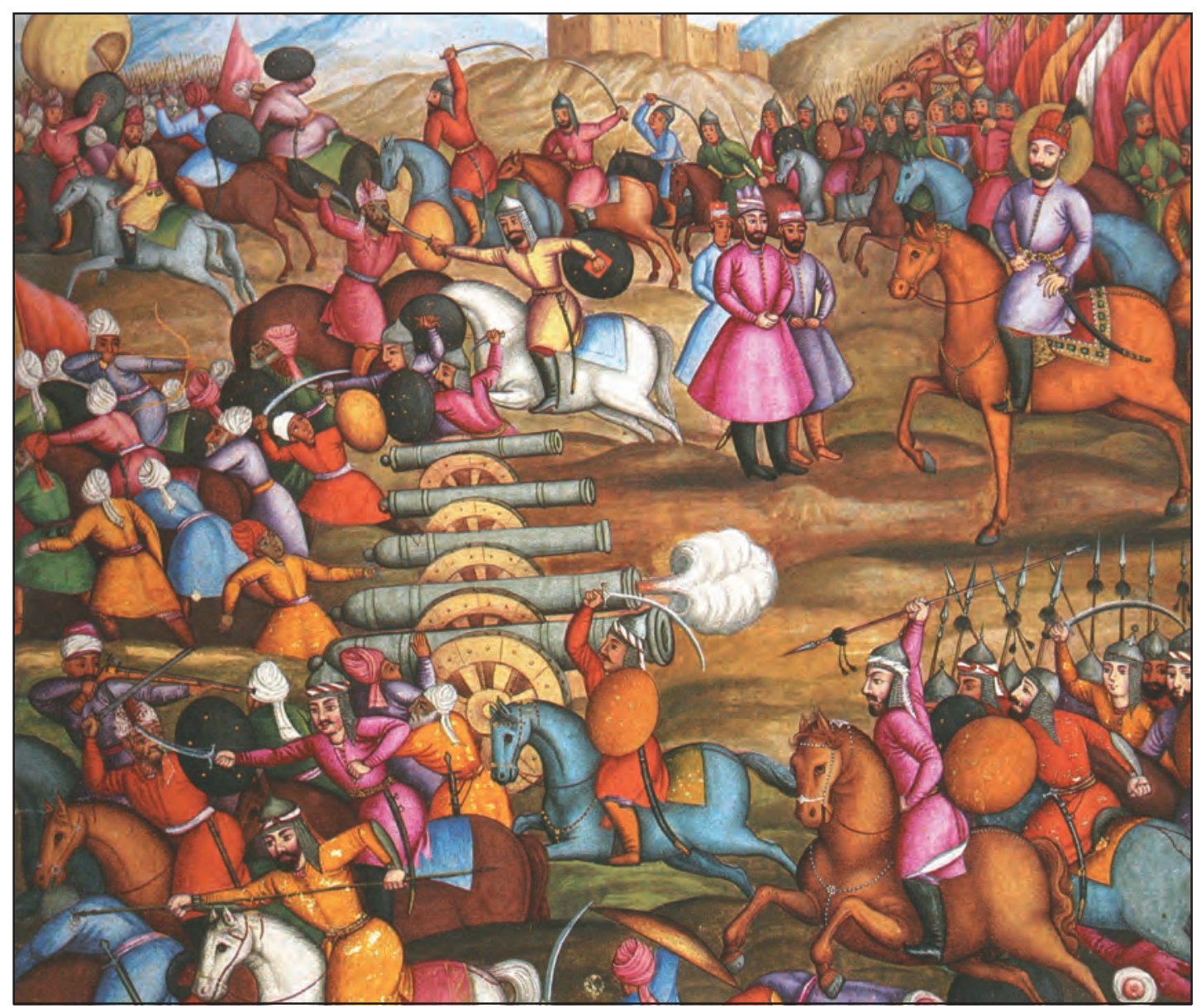

Figure 17. A miniature from the manuscript Tārix-e Jahāngošāy-e Nāderi [The History of the World Conquest of Nāder] shows the campaign between Nāder and the Afghans on the desert of Murče Xort, Isfahan. Note that Persian warriors are wearing spiked helmets.

\subsection{LeBĀS-E RAZM لباس رزم}

There are general terms to describe any type of armour or padding worn for protection before going to battle such as lebās-e razm لباس رزم (lit. war clothing). ${ }^{38}$ At times the expression lebās-e merixband لباس مريخبند (an armour with iron straps) is also used. ${ }^{39}$

\section{نمديوش NAMADPUŠ}

Most troops could not afford to buy expensive armour and were protected by felt. These were called namadpuš نمديوش (felt wearer; someone who uses felt as armour). ${ }^{40}$

38 See the $11^{\text {th }}$-century manuscript Samak Ayyār (al-Kāteb al-Rajāni, 2004/1383:1549).

39 See the manuscript Romuz-e Hamze (1940/1359 Hegira recollected in $15^{\text {th }}$-century).

40 See the $13^{\text {th }}$-century anthologyBustān (Sa'di, 2005/1383:242). 


\subsection{Q Qز اكند}

The term qazāgand is used by Dehxodā to refer to padding worn under the armour (see Digital Lexicon of Dehxodā). Dehxodā's explanation cannot be correct as qazāgand is armour in its own right. It consists of mail armour sandwiched between two layers of light padding. Usamah Ibn-Munqidh (1987:130-131) describes a particularly heavy version made with two layers of mail (p.130-131). Usamah talks about wearing a qazāgand قز آنَ constructed of two layers of mail during an incident when Saladin admonishes him for not donning his armour before a battle. He replies, «By Allah I can not put on anything more. We are in the early part of the night and my kazaghand [qazägand] is furnished with two coats of mail, one on top of the other. As soon as I see the enemy I shall put it on.» After the battle he demonstrated the armour's construction to Saladin. "I pulled out my knife and ripped it at the breast and disclosed the side of the two coats of mail. The kazagand [qazägand] enclosed a Frankish coat of mail extending to the bottom of it, with another coat of mail on top of it reaching as far as the middle. Both were equipped with the proper linings, felt pads, silk stuffing (al-lasin) and rabbits' hair.» In Europe this armour was called a jazerant and the word is probably a derivative of qazägand. In the Farhang-e Nafisi, Nafisi (1964/1343:2658, vol. 4) provides two meanings for qazāgand قز قز a) a cloth that is filled with wool and silk and worn in the battle and b) mail

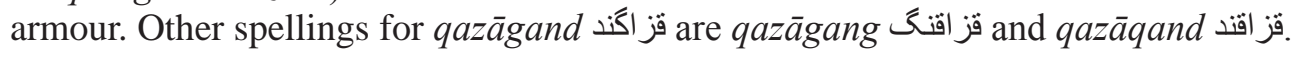

\subsection{RĀNBAND رانبند}

The thigh protector or a piece of armour meant for protecting the thigh was called rānband (Digital Lexicon of Dehxodā) or rānin رانيند (see the 12-century manuscript Ādāb al-Harb va al-Šojā-e, Mobārak Šāh Faxr-e Modabbar, 1967/1346:369).

\subsection{SĀQEDIN ساقدين}

The armour protecting the shin was called sāqedin ساقدين.411

\subsection{TANURE تنوره:}

Another type of armour mentioned by Persian manuscripts is tanure تنوره ${ }^{42}$ Based on the lexicons Borhān, Farhang-e Rašidi, and Farhang-e Jahāngiri, the Digital Lexicon of Dehxodā explains that tanure نتورهن is an armour made of mail and iron/steel plates similar to jǒšan however, the iron/steel plates (qeybe غييه) of are longer/bigger than the ones used in jŏšan جوشن.

41 See the $14^{\text {th }}$-century manuscriptMajma' al-Ansāb (Šabānkāre'i, 2002/1381:278)

42 For the usage the term tanure see the 12 $12^{\text {th }}$-century manuscript Šarafnāme (Nezāmi Ganje'i, 2007/1385a:127), the $19^{\text {th }}$-century manuscript Rostam al Tavārix (Āsef, 2003/1382:78), the 17 ${ }^{\text {th }}$-century manuscripts Resāle-ye Avval (1985/1374:157) and Resāle-ye Sevvom (Yazdi Šāhrudi, 1985/1374:268). 


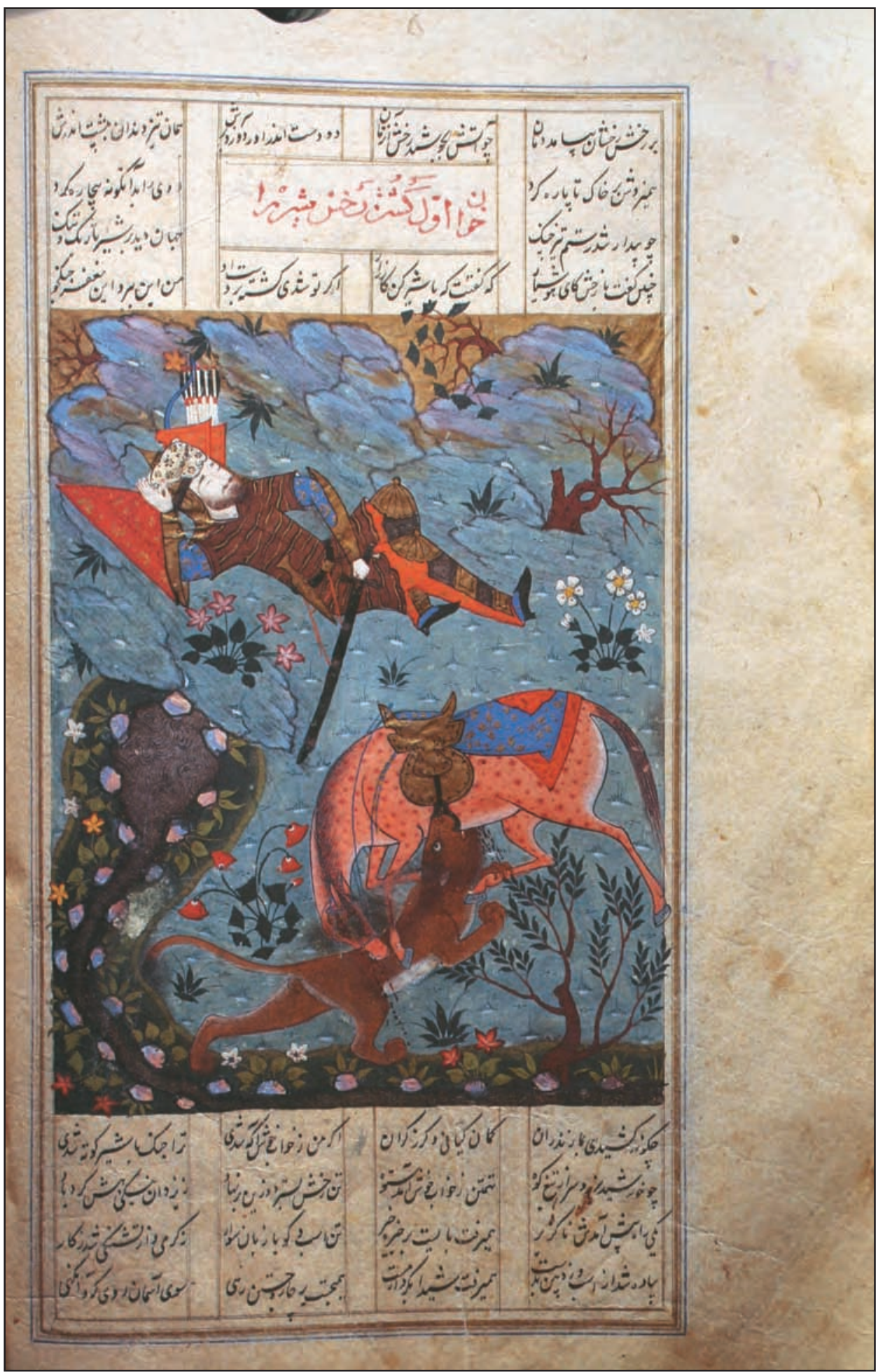

Figure 18. A miniature from a 16 century manuscript of the Šăhnāme shows Raxš fighting a lion (Courtesy of Sepahsālār Library). Note Rostam who is sleeping and wearing sāqedin ساقدين and knee protectors 


\section{خفتان 2.12 XAFTĀN}

Xaftān خفتان is the name of a padding worn under the armour. ${ }^{43}$ However, there are different descriptions in different period Persian mansucripts regarding how this was worn and from which material it was made. In the Digital Lexicon of Dehxodā, xaftān خفتان is described as a padding that is very thick and the fabric is made of silk or wool, which makes deflects the impact of sword strikes. It is also called qazāgand قز اكند and it was a very thick fabric from abrišam بشم (sool) which made the sword strikes slide off. The following verse from the $10^{\text {th }}$-century epic Šăhnāme in the chapter «Pādešāhi Xosrŏ Parviz» [The Rule of Xosrŏ Parviz] shows clearly that xaftān خفتان must have been a fabric or padding (Ferdŏsi, 1995/1384:1354):

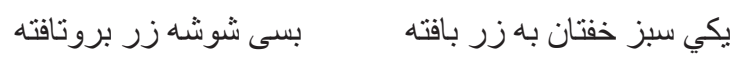

Yeki sabz xaftān be zar bāfte basi šuše zar baru bäfte

[He has knitted a green xaftān خفتان with gold [threads], he twined many gold ingots for it.

Ma'tufi (1999/1378:221) states that a xaftān خفتان or jivirak was worn under the jŏšan جوشن or zereh 0 joffering extra protection to the body. However, things even become more complicated when one checks the $11^{\text {th }}$-century epic Garšăsbnāme, where Asadi Tusi (1938:1317:101) describes that xaftān was worn on top of the mail armour:

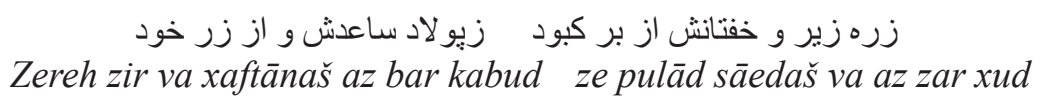

He was wearing the mail armour underneath and, above that, a blue xaftān خفتان, his underams were [armoured with] steel and his helmet was of gold.

This description is in line with the $11^{\text {th }}$-century manuscript Samak Ayyār , where it is described that xaftān خفتان was worn above zereh (mail armour) (al-Kāteb al-Rajāni, 2004/1383:927):

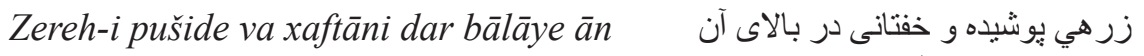

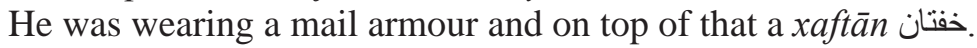

One should note that in Europe it was discovered that wearing padding above the mail gave better protection against longbow arrows. It is likely that the same thing was observed in Iran. Nevertheless, variations of wearing a xaftān خفتان existed as some period manuscripts report that xaftān خفتان was worn under mail armour. In the $19^{\text {th }}$-century manuscript Rostam al Tavārix, Āsef (2003/1382:240) explains that Ahmad Xān first put on qabā-ye pile duxte دوخته قباى يبله (a dress that half silk cocoons are sewn on for decorative purposes), and then on top of that a xaftān خفتان (a war padding), and then on top of that a zereh زره (mail armour) and on top of that a čahrāyne-ye fulād جهار آينه فو لاد (four mirrors made of steel plates). It seems that xaftān خفتان was worn under the armour, but at times similar to the usage in Europe, another padding was also worn on top of the mail armour to provide extra protection. However, other materials were also used to make a xaftān خفتان. The expression xaftān-e fulädi خفتان فو لادى) (a

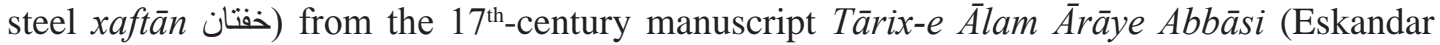
Beig Torkamān, 2003/1382:42) shows that a type of xaftān خفتان was made of steel. Also the

43 See the $10^{\text {th }}$-century epic Šāhnāme (Ferdǒsi, 1995/1384:191). 
$19^{\text {th }}$-century anthology Šahanšahnāme (Fathali Xān Sabā, 380) reports of xaftān-e āhan آهن

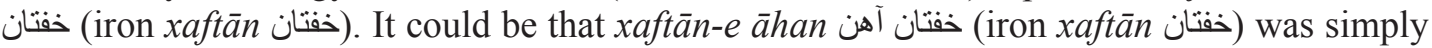
another way to describe a mail hauberk. ${ }^{44}$ There are Russian examples of mail that are tailored to look identical to civilian garments.

Persian manuscripts describe different materials for making a xaftān خفتان. These were either made of a) hide such as xaftān az pust-e babr خفتان از يوست بير: (a xaftān خفتان made of

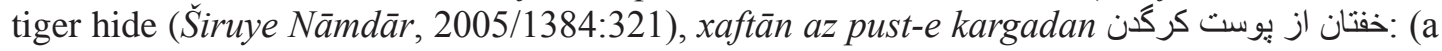

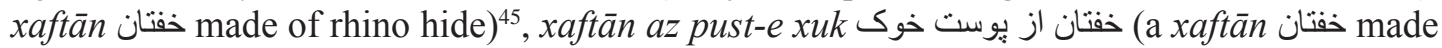

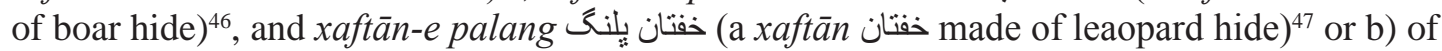

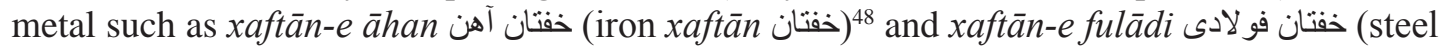
xaftān خفتان (خفتان آهن (خفتان (iron xaftān) or xaftān-e fulādi

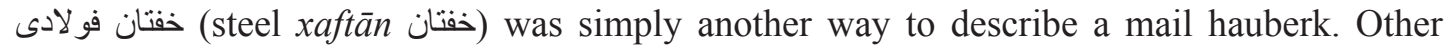
expressions in Persian manuscripts reveal where a xaftān خفتان was made such as xaftān-e

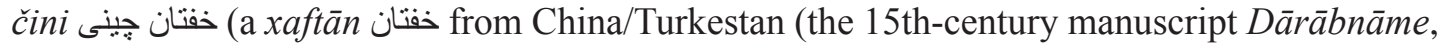
Beiqami, 2002/1381:529; vol.1), xaftān-e rumi: خفتان رومى (the Byzantine Roman/Anatolian armour padding ${ }^{50}$, and xaftān-e šoštari شفتان شُشترى (a attributed to šoštar شوشتر (šluštar) [a city in Xuzestān, name of a province in Iran] ${ }^{51}$. There are also expressions that describe

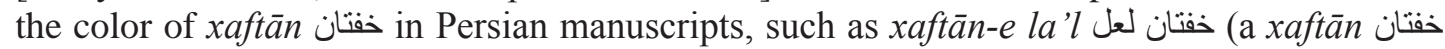
armour with the color of a ruby or a garnet) ${ }^{52}$, xaftān-e nārenji خفتان نارنجي (an orange-colored

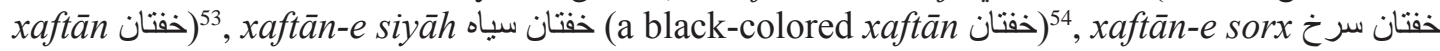

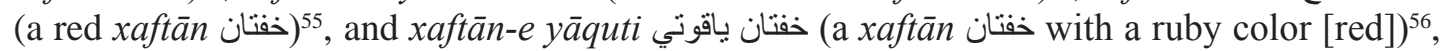
and simābgun xaftān سيمابكون خفتان (a xaftān خفتان (armour padding with a mercury color). ${ }^{57}$ Another synonym for xaftān خفتان was gabr or gabar see the $10^{\text {th }}$-century epic Šāhnāme, Ferdǒsi, 1995/1384:442):

$$
\text { زره دارد و جوشن و خود و كبر بغردَّ به كردار غرَّنده ابر }
$$

Zereh dārad va jöšan va xud va gabr beqorrad be kerdār qorrande abr

He is wearing mail armour, jŏšan جوشن armour, and a padding, he yells like a thundering cloud.

44 For the usage of the term xaftān خفتان in other Persian manuscripts see the $11^{\text {th }}$-century epic Garšāsbnāme (Asadi Tusi, 1938:1317:50), Veys va Rāmin (As'ad Gorgāni, 1970:1349:142), the 12 ${ }^{\text {th }}$-century manuscript Šarafnāme (Nezāmi Ganje'i, 2007/1385a:105), the $13^{\text {th }}$-century anthologyBustān (Sa'di, 2005/1383:242), the 12-century manuscript Ādāb al-

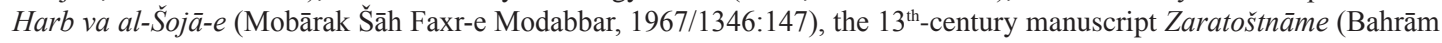
Paj̆dŏ, 1960/1338:75), Ardāvirāfnāme (Bahrām Paj̆dŏ, 1965/1343:29), the manuscript Romuz-e Hamze (1940/1359 Hegira:116) recollected in $15^{\text {th }}$-century, and Resāle-ye Čăhrom (1985/1374:399).

45 See the $12^{\text {th }}$-century manuscript Šarafnāme (Nezāmi Ganje'i, 2007/1385a:121).

46 See the $10^{\text {th }}$-century manuscript Abu Moslemnāme (Tartusi, 2001/1380:166; vol. 4).

47 See the $11^{\text {th }}$-century epic Garšāsbnāme (Asadi Tusi, 1938:1317:444).

48 See the $19^{\text {th }}$-century athology Šahanšahnāme (Fathali Xān Sabā, 380).

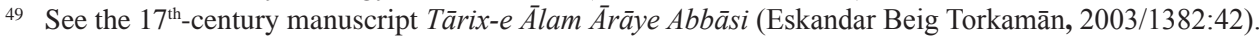

50 See the $10^{\text {th }}$-century epic Šăhnāme (Ferdŏsi, 1995/1384:351).

51 See the $10^{\text {th }}$-century manuscript Abu Moslemnāme (Tartusi, 2001/1380:205-206; vol. 2).

52 See the manuscript Širuye Nāmdār (2005/1384:189).

53 See the 15th-century manuscript Dārābnāme (Beiqami, 2002/1381:389; vol.1).

54 See the 15th-century manuscript Dārābnāme (Beiqami, 2002/1381:545; vol.1).

55 See the 15th-century manuscript Dārābnāme (Beiqami, 2002/1381:319; vol.1).

56 See the manuscript Romuz-e Hamze (1940/1359 Hegira:763) recollected in $15^{\text {th }}$-century.

57 See the $11^{\text {th }}$-century anthology Divān-e Mas'ud Sa'd Salmān (Sa'd Salmān, 1995/1374:361). 


\subsection{ZEREH ز ز}

The term zereh j jefers to mail armour. ${ }^{58} \mathrm{~A}$ mail armour consists of different iron/steel rings. Good quality ones were made of riveted links. A link of mail armour was called čambar-e zereh هنب زره داود (literally, a mail armour attributed to the Prophet Dāvud; riveted mail) 63 زره ميخكرد The term zereh-e dâvudi زره داودى is used to refer to a riveted mail, a sturdy mail with small rings that are linked through each other and riveted closed. A riveted mail ring is called halqeye mixi حلقه ميخي. If a ring has two rivets, it is called halqe-ye dokmixi حلقه دوميخي. In case of three rivets in a ring, the ring is called halqe-ye semixi حلقه ساميخي zereh dāvudi مرز داودى is a type of mail armour where sword strikes and arrows cannot pierce it. This term is used to describe mail made in the dẫvudi داودى style. It is different to (and likely superior to) zereh-e mamuli زرهه معدولي which is lighter and less resistant to arrows. A zereh-e mamuli زره معدولي is used to refer to mail armour with brazed or butted rings. A brazed mail link is called halqe-ye lahimi حلقه لحيمى. A combination of a riveted and brazed ring is called halqe-ye lahimi bā mix حلقه لحيمى با مين

The effectiveness of the mail armour is stressed in the $10^{\text {th }}$-century epic $\check{S} \bar{a} h n a \bar{a}$ e couple of times, such as in the following verse (Ferdǒsi, 1995/1384:1351):

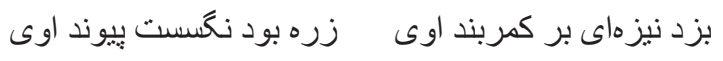

bezad neyze-I bar kamarband uy zereh bud nagosasat peyvand uy

He hit him with his spear on his belt [however] there was a mail armour and it did not tear it. Also see the $14^{\text {th }}$ century manuscript Târix-e Sistān (1992/1381:434).

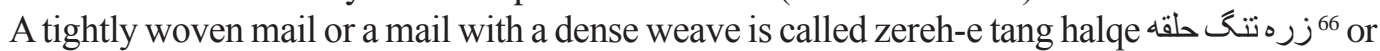
zereh-e xord halqe aقd a is named zereh-e tang halqe-ye dāvudi تنى داودى $0 j .{ }^{69}$ A mail armour with gilded or gold-inlaid rings was called zereh-e zarandud-e tang halqe Or zereh-i zarrin ${ }^{71}$ The lower part of the mail armour or the skirt of the mail armour was called zereh dāman

\footnotetext{
58 For the usage of the term zereh $\mathrm{j}$ see the $11^{\text {th }}$-century epic Garšāsbnāme (Asadi Tusi, 1938:1317:83), the $11^{\text {th }}$ century manuscript Tārix-e Beyhaqi (Beyhaqi, 2004/1383:135), and the 10 $0^{\text {th }}$-century manuscript Abu Moslemnäme (Tartusi, 2001/1380:269).

59 See the manuscript Tarix-e Ālam Āryā-ye Amini (Xonji Esfahāni, 2003/1382:149).

60 See the $11^{\text {th }}$-century anthology Divān-e Manučehri Dāmqāni (Manučehri Dāmqāni, 1984/1363:18).

61 See the manuscript Romuz-e Hamze (1940/1359 Hegira:59) that was recollected in $15^{\text {th }}$-century.

62 For the usage of the term zereh-e dāvudi زره داودى see the $11^{\text {th }}$-century anthology Divān-e Manučehri Dāmqāni (Manučehri Dāmqāni, 1984/1363:178), the manuscript Dārābnāme-ye Tarsusi (Tarsusi, 1977/2536;45, vol. 1)that was based on old Pahlavi texts; and the 11 ${ }^{\text {th }}$-century manuscript Samak Ayyār (al-Kāteb al-Rajāni, 2004/1383:391)

63 See Šahidi (2001/1380:405).

64 See Romanowsky (1967c/1346: picture 27).

65 Idem.

66 See the Safavid-period manuscript Ālam Ārāye Šāh Tahmāsp (1991/1370:59).

67 See the manuscript Dārābnāme-ye Tarsus (Tarsusi, 1977/2536:134, vol. 2) that was based on old Pahlavi texts.

68 See the manuscript Širuye Nāmdār (2005/1384:77).

69 See the Safavid-period manuscript Dāstān-e Hosseyn Kord-e Šabestari (2003/1382:30 and the manuscript Širuye Nāmdār (2005/1384:410).

70 See the $10^{\text {th }}$-century manuscript $A b u$ Moslemnāme (Tartusi, 2001/1380:365; vol. 3).

71 See the $14^{\text {th }}$-cenury manuscript Majma' al-Ansāb (Šabānkāre'i, 2002/1381:278).

72 See the theDigital Lexicon of Dehxodā.
} 
āstin-e zereh زرهـ آستين زره ${ }^{74}$, and the padded area on the neck part of the mail armour for providing extra protection so that the rings would not injure the neck was called baleštak

Sometimes Persian manuscripts reveal where a type of mail armour was made such as zereh-e quriyāne زره غوريانه (a type of mail armour from Quriyān, a place on the eastern side of the fortification wall of Buxārāa) ${ }^{76}$, zereh-e soqdi زره سغدى (the Soghdian mail armour) ${ }^{77}$, and

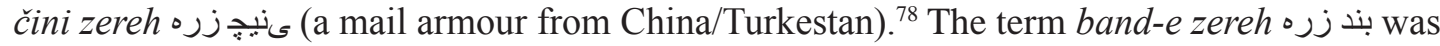
used to refer to the straps that tighten the mail armour. ${ }^{79}$ Some expressions also describe the color of the mail armour such as meškin zereh مشكين زرم (black/dark mail armour). ${ }^{80}$ A gilded

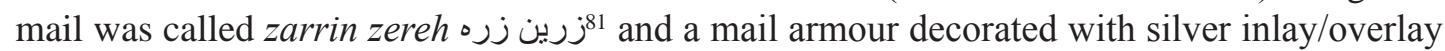

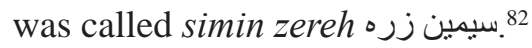

A craftsman who made mail armour was called zerehbāf

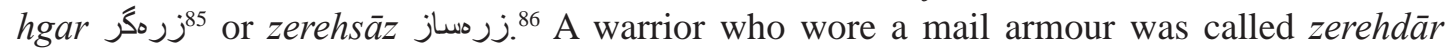

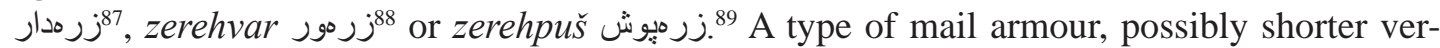
sions, was called zerehin هين جنحى جهارده تكه زره.

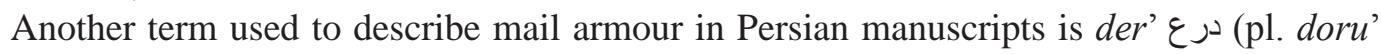

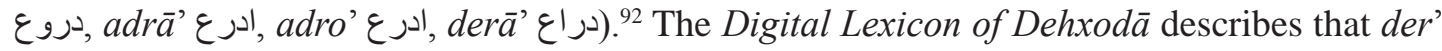
is a cloth that is made/weaved from iron mail and is used to protect the body during the battle. ${ }^{93}$ The expression der'-e mozarrad درع مزرد (mail armour with rings) reveals that der' داودى درع was indeed a mail armour that consisted of rings.

73 See the Safavid-period manuscript Dāstān Hosseyn Kord-e Šabestari (Dāstān Hosseyn Kord-e Šabestari, 2003/1382:30)

74 See the $11^{\text {th }}$-century epic Garšāsbnāme (Asadi Tusi, 1938:1317:448).

75 See Šahidi (2001/1380:405).

76 See the $10^{\text {th }}$-century manuscript $A b u$ Moslemnāme (Tartusi, 2001/1380:269; vol. 2).

77 See the $11^{\text {th }}$-century epic Garšās snāme (Asadi Tusi, 1938:1317:331).

78 See the $19^{\text {th }}$-century athology Šahanšahnāme (Fathali Xān Sabā, 206).

79 See the $10^{\text {th }}$-century epic Šăhnāme (Ferdŏsi, 1995/1384:1321).

80 See the $11^{\text {th }}$-century epic Garšās

81 See the $19^{\text {th }}$-century athology Šahanšahnāme (Fathali Xān Sabā, 237).

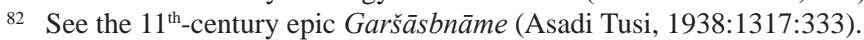

83 See the Digital Lexicon of Dehxodā.

84 See Ma'tufi (1999/1378:446) and the Digital Lexicon of Dehxodā.

85 See the $11^{\text {th }}$-century anthology Divān-e Manučehri Dāmqāni (Manučehri Dāmqāni, 1984/1363:60) and Manteq al-Teyr (Attār Neišāburi, 1993/1372:2).

${ }_{86}$ See the $19^{\text {th}}$-century manuscripts Rostam al Tavārix (Āsef, 2003/1382:89) and Jogrāfiyā-ye Esfahān (Tahvildār Esfahāni, 1964/1342:109)

87 See the $10^{\text {th }}$-century epic Šăhnāme (Ferdǒsi, 1995/1384:284).

88 See Moxtārnāme (Attār Neišāburi, 1979/1358:179).

89 See the $11^{\text {th }}$-century epic Garšăsbnāme (Asadi Tusi, 1938:1317) and the $11^{\text {th }}$-century manuscript Tārix-e Beyhaqi (Beyhaqi, 2004/1383:540).

90 See the 12-century manuscript $\bar{A} d \bar{a} b$ al-Harb va al-Šojā-e (Mobārak Šāh Faxr-e Modabbar, 1967/1346:369).

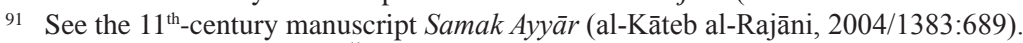

92 See the $10^{\text {th }}$-century epic Šăhnāme (Ferdǒsi, 1995/1384:191).

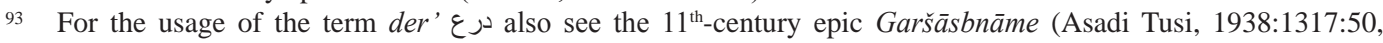
112), the $11^{\text {th }}$-century anthology Divān-e Qatrān-e Tabrizi (Qatrān-e Tabrizi, 1983/1362:407), the $14^{\text {th }}$-century manuscript Zafarnāme (Mostufi, 1999/1377:1252), the 17th-century manuscript Tārix-e Ālam Ārāye Abbāsi (Eskandar Beig Torkamān, 2003/1382:701), and the 18-th century manuscript Tārix-e Jahāngošāy-e Nāderi (Esterābādi, 1991/1370:12). For the plural usage of this word, see the $17^{\text {th }}$-century manuscript Rozat al-Safaviye (Jonābodi, 1999/1378:789).

94 See the $11^{\text {th }}$-century anthology Divān-e Manučehri Dāmqāni (Manučehri Dāmqāni, 1984/1363:18). 
درع (a riveted mail armour) shows that the rings of der' درع were riveted. ${ }^{95}$ The following الحديد armour were made of iron such as der' al-hadid درع ' درع ' درع (an iron mail armour) ${ }^{96}$ and der'-e āhan درع آهن (an iron mail armour) ${ }^{97}$ and others made of steel such as pulād der' بو لاد درع (mail armour made of steel). mail armour was combined with padding such as der'va xaftān درع وع (mail armour and padding) ${ }^{99}$ and der' va xaftān-e mokammel درع و خفتان مكمل (mail armour and padding which complete each other; which go together). ${ }^{100}$ The person who was wearing a mail armour was

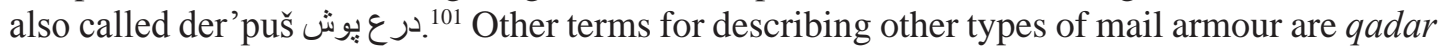

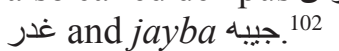

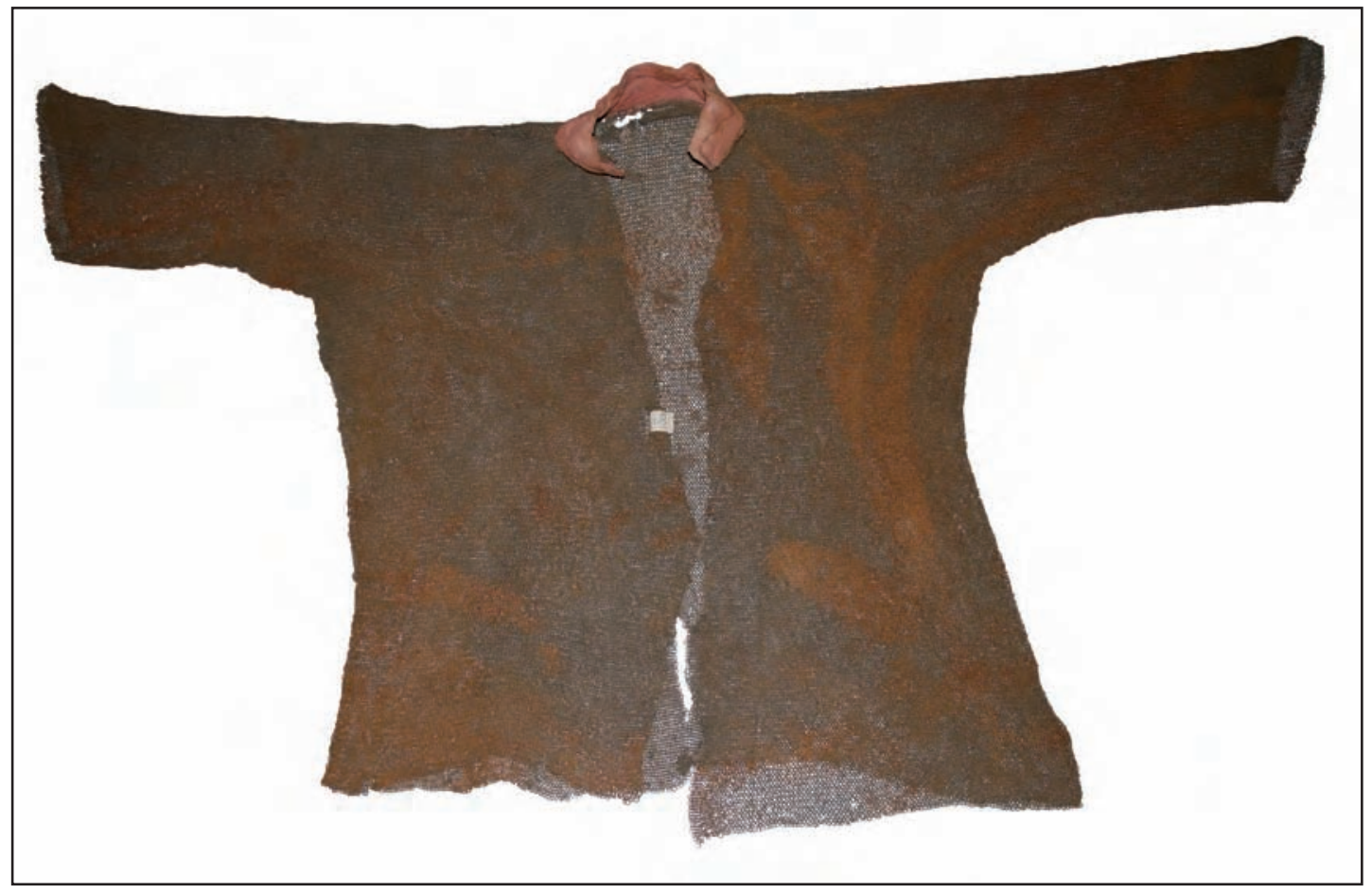

Figure 19. A riveted mail armour from the early Qājār period (1794-1925 C.E.) (Courtesy of the Cultural Institute of Bonyād).

95 See the 12-century manuscript Haft Peykar (Nezāmi Ganje'i, 1999/1377:133) and the $19^{\text {th }}$-century epic Šāhnāmeye Nāderi (Nāderi, 1968/1346:249).

96 See the Digital Lexicon of Dehxodā.

97 See the 12th-century manuscript Haft Peykar (Nezāmi Ganje'i, 1999/1377:106).

98 See the Digital Lexicon of Dehxodā.

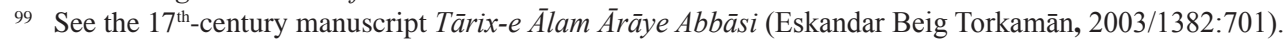

100 See the 18th-century manuscript Tārix-e Jahāngošāy-e Nāderi (Esterābādi, 1991/1370:12).

101 See the $11^{\text {th }}$-century epic Garšăsbnāme (Asadi Tusi, 1938:1317:253) and the $19^{\text {th }}$-century anthology Šahanšahnāme (Fathali Xān Sabā, 261).

102 See the Digital Lexicon of Dehxodā. 


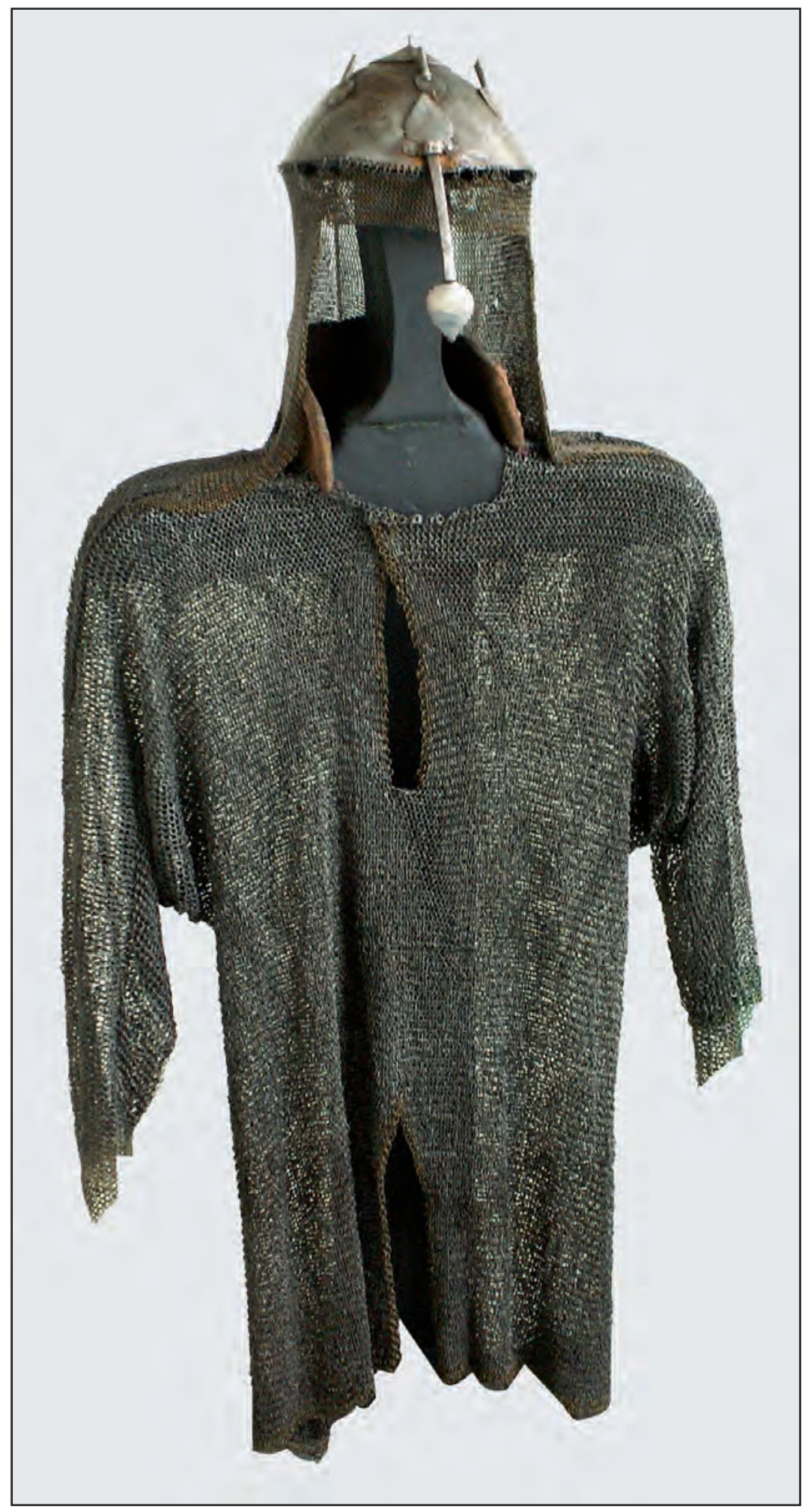

Figure 20. A riveted mail armor attributed to the era of Fath Ali Šāh Qājār (1797-1834 C.E.) (Courtesy of the Military Museum of Bandar Anzali). 


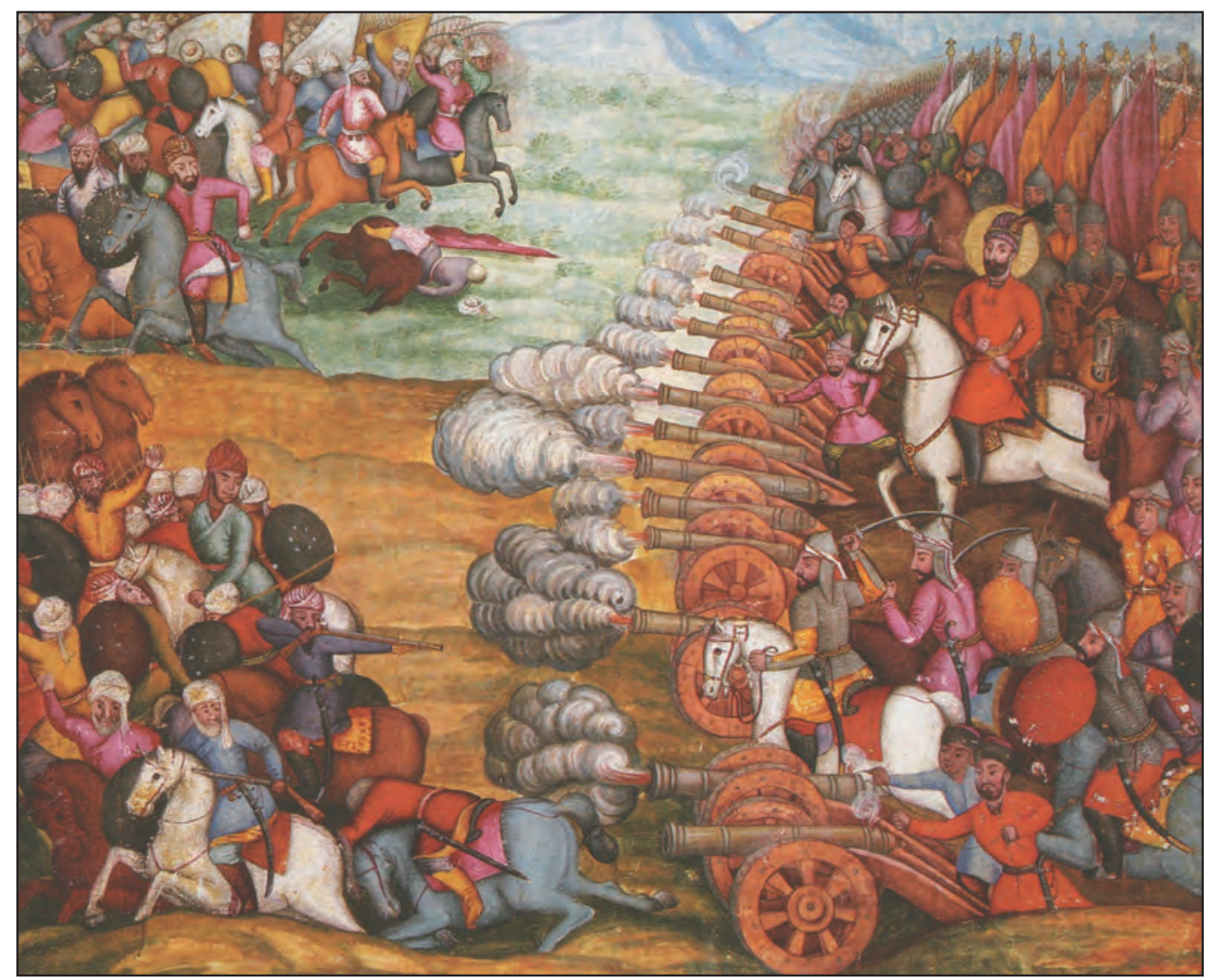

Figure 21. A miniature from the manuscript Tārix-e Jahāngošāy-e Nāderi [The History of the World Conquest of Nāder] shows the majority of Persian warriors depicted on the right side wearing mail armour. The painting depicts the campaign between Nāder and Ašraf the Afghan at Mehmāndust, Damqān. The Afghans are fleeing away.

\section{زرمكلاه}

A mail coif/ mail hood, meaning a mail armour covering the head and at times the face, was called zerehkolāh 105 زرمخود The eye opening/slit or the link of an eye opening in the mail hood was called halqe-ye češm-e zereh

\subsection{SALIH سليح}

There are some terms describing armour that cannot be specifically attributed to a certain type of armour. One of them is salih سليح (see the $10^{\text {th }}$-century epic Šāhnāme, Ferdŏsi, 1995/1384:348) $)^{107}$ :

\footnotetext{
103 Ibid.

${ }^{104}$ See the manuscript Romuz-e Hamze (1940/1359 Hegira:698) that was recollected in $15^{\text {th }}$-century.

105 See the Digital Lexicon of Dehxodā.

106 See the 18 $18^{\text {th}}$-century manuscript Tārix-e Ahmad Šāhi (al-Jāmi, 2001/1379:395).

107 For the usage of the term salih سليح also see the 11 ${ }^{\text {th }}$-century epic Garšāsbnāme (Asadi Tusi, 1938:1317:70).
} 
سليح سياوش بيوشد به جنى نتدسر ز بيكان تير خدنى

Salih Siavaš bepušad be jang natarsad ze peykān-e tir-e xadang

Siavaš put on his armour for war [and therefore, he] will not be afraid of the arrowhead of the arrow made of poplar.

\section{ANIMAL ARMOUR}

Animal armour found in the Persian manuscripts can be divided into: II.1 āyne آينه and

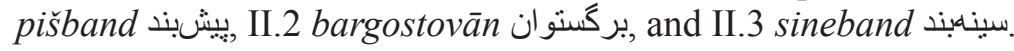

\section{ييشبند AND PIŠBAND}

The term āyne آينه used in reference to animal armour describes the chanfron protecting the forehead of a horse or an elephant. The term ayne آيند is usually used in combination such as āyne-ye pulād bar pišāni-ye markab آينه يو لاد بر بيشاني مركب (lit. the steel mirror/plate on the horse's forehead; steel chanfron. ${ }^{108}$ At times the Persian manuscripts also reveal where the aniجينى بر بيشاني اسب آينه (lit. the steel mirror/plate from China/Turkestan on the horse's forehead; steel chanfron). ${ }^{109}$ Another synonym for the term ayyne بيشبند is is pišband (chanfron). ${ }^{110}$ Some expressions reveal that it was made of steel as in the expressions pišband-e fulād بيشبند وفلاد (steel chanfron) ${ }^{111}$ and pišband-e fuläd bar pišāni-ye markab بيشبند فو لاد بر بيشاني مركب (lit. the steel front cover on the horse's forehead; chanfron). ${ }^{112}$ Other expressions reveal were some chanfrons were made such as pišband az āyne-ye čini بيشبند از آينه جينى (chanfron made of Chinese steel plate/ steel plate from Turkestan) ${ }^{113}$, pišband az àyne-ye farangi بيشبند از آينه فرنكي (chanfron made of foreign steel plate) ${ }^{114}$, and pišband az fulād-e čini بيشبند از فو لادي جينى (Dārābnāme) (chanfron made of Chinese steel/ steel from Turkestan). ${ }^{115}$

\subsection{BARGOSTOVĀN}

Generally, the term bargostovān بركستوان is used to refer to the horse armour (see the $10^{\text {th }}$-century epic Šāhnāme, Ferdŏsi, 1995/1384:284). ${ }^{116}$ In combination this word is also used to refer to other types of animal armour such as bargostovān-e pil بركستو ان بيل (an elephant armour). ${ }^{117}$ Dehxodā explains that bargostovān بركستو ان is normally used to refer to horse and

\footnotetext{
108 See the 15th-century manuscript Dārābnāme (Beiqami, 2002/1381:343; vol.1).

109 See the 15th-century manuscript the 15th-century manuscript Dārābnāme (Beiqami, 2002/1381:452; vol.1).

110 See the 15th-century manuscript Dārābnāme (Beiqami, 2002/1381:545; vol. 1).

111 See the 15th-century manuscript Dārābnāme (Beiqami, 2002/1381:409; vol.1).

112 See the 15th-century manuscript Dārābnāme (Beiqami, 2002/1381:319; vol.1).

113 See the 15th-century manuscript Dārāanbnäme (Beiqami, 2002/1381:545; vol. 1).

114 See the 15th-century manuscript Dārābnāme (Beiqami, 2002/1381:640; vol.2).

115 See the 15th-century manuscript Dārābnāme (Beiqami, 2002/1381:529; vol.1).

${ }^{116}$ For the usage of the term bargostovān بركَّتوان also see the $10^{\text {th }}$-century epic Goštāsbnāme (Daqiqi Tusi, 1994/1373:76), the $11^{\text {th }}$-century epic Garšăsbnāme (Asadi Tusi, 1938:1317:45), the $11^{\text {th }}$-century manuscript Tārix-e Beyhaqi (Beyhaqi, 2004/1383:69), Qazaliāt (Sa'di, 2005/1383:315), the 12-century manuscript Ādāb al-Harb va alŠojā-e (Mobārak Šāh Faxr-e Modabbar, 1967/1346:147), the 13 ${ }^{\text {th }}$-century manuscript Zaratoštnāme (Bahrām Pă̌dŏ, 1960/1338:75), the 15th-century manuscript Zafarnāmee (Yazdi, 1957/1336a:254), and the $19^{\text {th }}$-century manuscript Rostam al Tavārix (Āsef, 2003/1382:78).

117 See the manuscript Dārābnäme-ye Tarsus (Tarsusi, 1977/2536:161, vol. 2) that is based on old Pahlavi texts.
} 


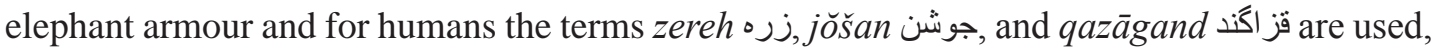
but bargostovān بركستو ان sometimes used to refer to human armour as well. Also note that an

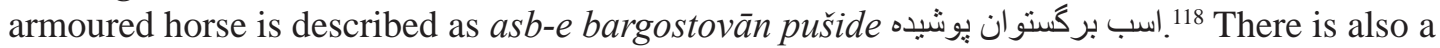
term describing an elephant clad in mail armour such as fil-e zerehpuš فيل زرديوني (an elephant in mail armour). ${ }^{119}$

Persian manuscripts report of different materials for making a horse armour such as a) iron/steel such as the expressions bargostovān-e āhanin بركسنو ان آهنين (an iron horse armour) بركَ (20) and bargostovān az àyne-ye čini بركستو ان از آينه جِينى (a horse armour made of [steel/iron] mirror/plates from China/Turkestan). ${ }^{121}$ In this respect, Persian manuscripts also report of iron/

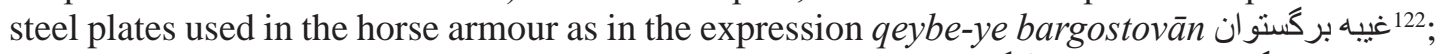

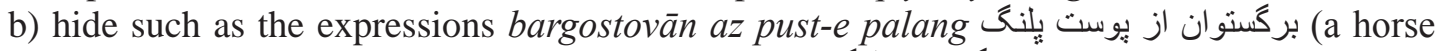
armour of leopard hide) $)^{123}$ and bargostovān-e palang بركستوان يلنح (a horse armour of leopard hide). ${ }^{124}$ Perhaps it should be horse armour covered with leopard hide (i.e. the leopard hide is only a decorative cover and not the functional part of the armour) as leopard hide is not, unlike buffalo or rhino hide, sturdy and tough enough to serve as an armour on its own or the expression bargostovān az xaz بركستو ان از خز (horse armour made of fur) ${ }^{125}$, and c) fabric, such as the

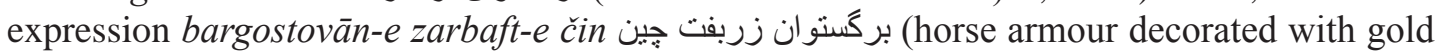
brocade from China/Turkestan). ${ }^{126}$ A horse armour made of hide was also called badanče az čarm-e gāvmiš بدنجه از جرم كَاو ميش

Some expressions also describe where a bargostovān بركستوان was made, such as bargostovān-e čin بركستوان جين: (horse armour from China/Turkestan) ${ }^{128}$ and bargostovān-e rumi بركستوان رومى (a Roman/Anatolian horse armour).

There are also expressions that describe the different variance of colors of bargostovān such as bargostovān-e banafšs بركستو ان بركستو ان (a purple horse armour) ${ }^{130}$, bargostovān-e

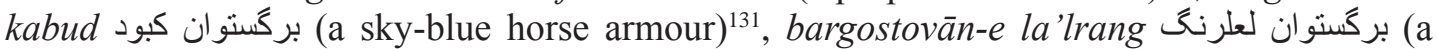

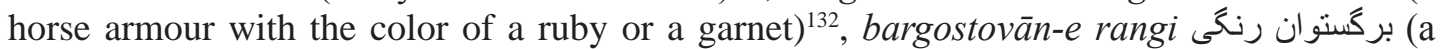
colored horse armour) ${ }^{133}$, bargostovān-e sabz بركستو ان سبز (a green-colored horse armour) ${ }^{134}$, and bargostovān-e siyāh بركستوان سياه (a black-colored horse armour). ${ }^{135}$ Other expressions describe different types of gold-inlaying or gilding on bargostovān بركسئو as bargostovān-e zar بركستوان زرد (lit. a golden horse armour; a gilded horse armour) بركون ${ }^{136}$ and bargostovān-e zarandud بركستو ان زر اندود زرد (gold-inlaid/gold-overlaid horse armour). ${ }^{137}$ There are

\footnotetext{
118 See the $19^{\text {th }}$-century manuscript Rostam al Tavārix (Āsef, 2003/1382:120).

119 See the $18^{\text {th }}$-century manuscript Tārix-e Ahmad Šăhi (al-Jāmi, 2001/1379:408).

120 See the 12-century manuscript $\bar{A} d \bar{a} b$ al-Harb va al-Šojā-e (Mobārak Šāh Faxr-e Modabbar, 1967/1346:252).

121 See the 15th-century manuscript Dārābnāme (Beiqami, 2002/1381:293; vol.1).

122 See the Digital Lexicon of Dehxodā.

123 See the 15th-century manuscript Dārābnāme (Beiqami, 2002/1381:623; vol.1).

124 See the 15th-century manuscript Zafarnāme (Yazdi, 1957/1336a:362).

125 See the $11^{\text {th }}$-century anthology Divān-e Mas'ud Sa'd Salmān (Sa'd Salmān, 1995/1374:381).

126 See the $11^{\text {th }}$-century epic Garšāsbnāme (Asadi Tusi, 1938:1317:205).

127 See the $10^{\text {th }}$-century manuscript Abu Moslemnāme (Tartusi, 2001/1380:206; vol. 3).

128 See the $11^{\text {th }}$-century epic Garšāsbnāme (Asadi Tusi, 1938:1317:331).

129 See the manuscript Dārābnāme-ye Tarsusi that is based on old Pahlavi texts (Tarsusi, 1977/2536, vol. 2).

130 See the $11^{\text {th }}$-century epic Garšās bnāme (Asadi Tusi, 1938:1317:101).

131 See the 15th-century manuscript Dārābnāme (Beiqami, 2002/1381:281; vol.2).

132 See the $11^{\text {th }}$-century epic Garšās bnāme (Asadi Tusi, 1938:1317:444).

133 See the $10^{\text {th }}$-century manuscript Abu Moslemnāme (Tartusi, 2001/1380:199; vol. 4).

134 See the 15th-century manuscript Dārābnāme (Beiqami, 2002/1381:319; vol.1).

135 See the 15th-century manuscript Dārābnāme (Beiqami, 2002/1381:343; vol.1).

136 See the $10^{\text {th }}$-century manuscript Abu Moslemnāme (Tartusi, 2001/1380:458; vol. 3).

137 See the $10^{\text {th }}$-century manuscript Abu Moslemnāme (Tartusi, 2001/1380:206; vol. 3).
} 
also terms that describe an armoured horse or elephant such as bargostovāndār بركَّكستواندار (an armoured horse or elephant) بركَتو انكش (an armoured horse or elephant ${ }^{139}$, and bargostovānvar بركستو انور (an armoured horse or elephant). ${ }^{140}$ A horse armour which can-

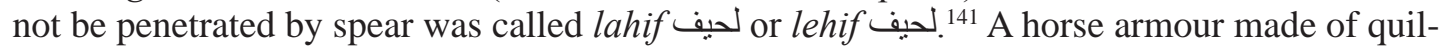
ted padding stuffed with straw was called jŏšan-e hasiri satar جوشن حصيرى ستر

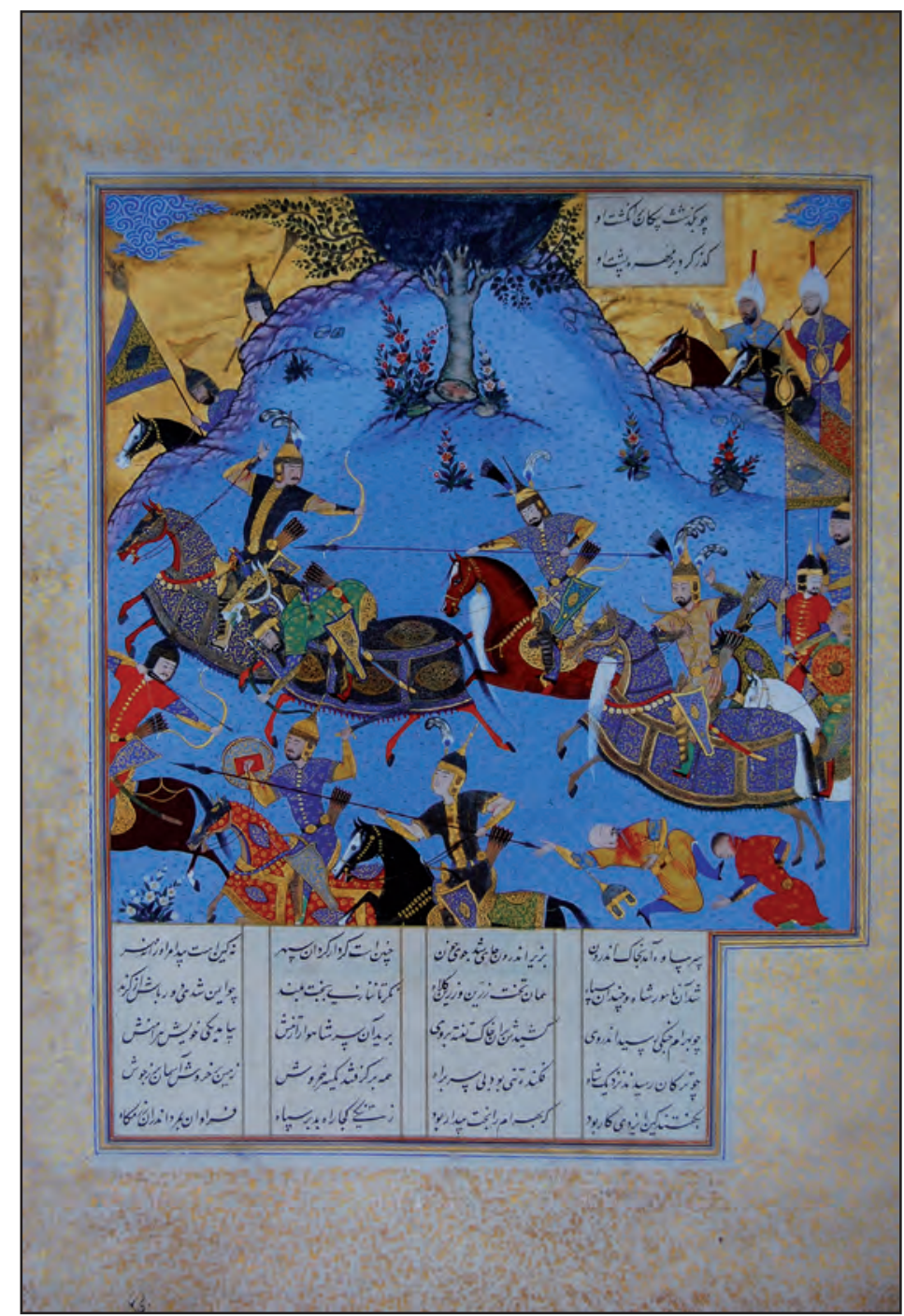

Figure 22. A miniature from a manuscript of Šāhnāme-ye Tahmāspi dated 944 Hegira (1537 C.E.) shows Bahrām Čubin killing Sāveh Sāh in the battle. Note the bargostovān of the horses (Courtesy of Rezā Abbāsi Museum).

\footnotetext{
138 See the $11^{\text {th }}$-century epic Garšās snāme (Asadi Tusi, 1938:1317:101).

139 See the Digital Lexicon of Dehxodā.

140 Ibid.

141 See the $12^{\text {th }}$-century manuscript Šarafnāme (Nezāmi Ganje'i, 2007/1385a:114).

142 See the 14th-century manuscript Zafarnāme (Mostufi, 1999/177:443).377:443).
} 


\section{سينهبند SINEBAND}

The plate that protected the horse chest was called sineband-e asb 143

\section{SUMMARY}

Different types of armour can be generally divided into human armour and animal armour. Human armour consisted of different parts. In this summary, I will name the most important and common types. The padding which was worn under the armour was called xaftân خفتان. Sometimes this padding was called qazāgand قز اگتزد. However, one should note that qazāgand قز اكند ding. The garibān كريبان was a type of mail armour that protected the neck but also provided extra protection for the upper breast. Then a piece of armour named čāhrâyne جهار آينه was worn over the mail armour. The čāhrāyne جهار آينه consisted of four steel plates, two for protecting the chest and back areas (breast- and backplates) and two for protecting the sides (side

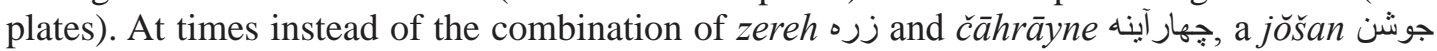
was worn which was a type of mail-and-plate armour and some types were made of hide. The

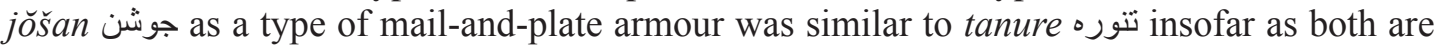
made from mail and iron/steel plates; however, the iron/steel plates (qeybe غوشن are shorter/smaller than the ones used in tanure تنوره. A pair of bāzuband بازوبند was used in Iran for protecting the forearms during combat. The kolāhxud كلاه خود wast was used to protect the head of the warriors. Sometimes instead of a kolāhxud ككاه خود, a zerehkolāh زردكلاه (mail coif)

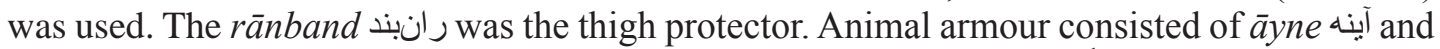
pišband بيشبند to protect the forehead of an animal, bargostovān بركستو ان to protect the body, and sineband سينبند to protect the chest.

\section{(Endnotes)}

For the phonetic transcription of the Persian words, the system of Persian transcription in Dā'eratolmaāref-e Bozorg-e Eslāmi [The Great Islamic Encyclopaedia] by Mohammad Hasan Semsār (1997/1377) published in Tehran is used. The following table shows the table of the phonetical alphabet used for the New Persian transcriptions:

\begin{tabular}{|c|c|c|}
\hline \multicolumn{3}{|c|}{ Phonetics of the New Persian used in the lexicon } \\
\hline$\overline{\mathbf{a}}$ & The sound $\overline{\mathbf{a}}$ as in the English word jar & The sound $\overline{\mathbf{a}}$ as in the Persian word $\overline{\boldsymbol{a}} b$ آب \\
\hline a & The sound $\mathbf{a}$ as in the English word after & The sound a as in the Persian word asb اسب. \\
\hline b & The sound $\mathbf{b}$ as in the English word boy & The sound $\mathbf{b}$ as in the Persian word $\boldsymbol{b}$ and \\
\hline$\check{\mathbf{c}}$ & The sound $\check{\mathbf{c}}$ as in the English word chair & 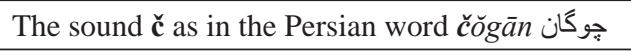 \\
\hline d & The sound $\mathbf{d}$ as in the English word direction & داروغه The sound $\mathbf{d}$ as in the Persian word dāruqe \\
\hline $\mathbf{e}$ & The sound $\mathbf{e}$ as in the German word Ersatz & The sound e as in the Persian word ehsān احسان \\
\hline $\mathbf{f}$ & The sound $\mathbf{f}$ as in the English word future & فلاخن The sound f as in the Persian word falāxon \\
\hline g & The sound $\mathbf{g}$ as in the English word goat & كَردن The sound $\mathbf{g}$ as in the Persian word gardan \\
\hline $\mathbf{h}$ & The sound $\mathbf{h}$ as in the English word home & The sound $\mathbf{h}$ as in the Persian word $\mathbf{h} \overline{a m m}$ هامون \\
\hline
\end{tabular}

${ }^{143}$ See the Digital Lexicon of Dehxodā. 


\begin{tabular}{|c|c|c|}
\hline i & The sound long $\mathbf{i}$ as in the English word need & ايران The sound long i as in the Persian word Irān \\
\hline j & The sound $\mathbf{j}$ as in the English word jacket & جاسوس The sound j as in the Persian word $\mathbf{j a ̄ s u s}$ \\
\hline 通 & The sound $\mathbf{j}$ as in the French word jambe & رُويين The sound y as in the Persian word jupin \\
\hline $\mathbf{k}$ & The sound $\mathbf{k}$ as in the English word key & The sound $\mathbf{k}$ as in the Persian word $\mathbf{k} \bar{a} r d$ كارد \\
\hline 1 & The sound $\mathbf{I}$ as in the English word lock & The sound $\mathbf{I}$ as in the Persian word Iašgar لشغر \\
\hline $\mathbf{m}$ & The sound $\mathbf{m}$ as in the English word middle & The sound $\mathbf{m}$ as in the Persian word $\boldsymbol{m} \bar{a} r$ مار \\
\hline n & The sound $\mathbf{n}$ as in the English word nobility & The sound $\mathbf{n}$ as in the Persian word namak \\
\hline $\mathbf{0}$ & The sound $\mathbf{o}$ as in the German word offen & Tقاب The sound $\mathbf{0}$ as in the Persian word $\boldsymbol{o} q \bar{a} b$ \\
\hline$\breve{\mathbf{0}}$ & A sound combination of $\mathbf{o}$ and $\mathbf{u}$ & كو هر The sound \\
\hline $\mathbf{p}$ & The sound $\mathbf{p}$ as in the English word parish & The sound $\mathbf{p}$ as in the Persian word $\mathbf{p a r}$ \\
\hline $\mathbf{q}$ & The sound $\mathbf{q}$ as in the French word recherché & قمه The sound $\mathbf{q}$ as in the Persian word qame \\
\hline $\mathbf{r}$ & The sound $\mathbf{r}$ as in the English word relief & The sound r as in the rax̌̌ رخش \\
\hline s & The sound $\mathbf{s}$ as in the English word sound & ساطور The sound s as in the Persian word sātur \\
\hline$\check{\mathbf{s}}$ & The sound š as in the English word shop & شششير The sound š as in the Persian word šamšir \\
\hline $\mathbf{t}$ & The sound $\mathbf{t}$ as in the English word teacher & The sound $\mathbf{t}$ as in the Persian word $\mathbf{t}$ abar تبر \\
\hline $\mathbf{u}$ & The sound $\mathbf{u}$ as in the German word Urheber & آهنيوش The sound u as in the Persian word āhanpuš \\
\hline $\mathbf{v}$ & The sound $\mathbf{v}$ as in the English word verse & ولايت The sound v as in the Persian word velāyat \\
\hline $\mathbf{x}$ & The sound $\mathbf{x}$ as in the Spanish word jamon & خانه The sound $\mathbf{x}$ as in the Persian word $x \overline{a n e}$ \\
\hline $\mathbf{y}$ & The sound $\mathbf{y}$ as in the English word yard & يكران The sound y as in the Persian word yekrān \\
\hline $\mathbf{z}$ & The sound $\mathbf{z}$ as in the English word zebra & The sound $\mathbf{z}$ as in the Persian word $z \bar{a} j j$ j \\
\hline
\end{tabular}

\section{BIBLIOGRAPHY}

\section{Primary sources}

Ālam Ārāye Šāh Tahmāsp (1991/1370). Zendegani Dāstāni Dovomin Padešāh-e Doreye Safavi [The Narrative Biography of the Second Safavid King]. Edited and annotated by Iraj Afs̃ār. Tehrān: Entešāāt-e Donyāye Ketāb.

Āsef, M. H. (2003/1382). Rostam al Tavārix: Salatin-e Selseleye Safaviye, Afšāriye, Zandiye va Qājāriye. [Rostam al Tavārix: The Sultans of Safavid, Afsāarid, Zand and Qājār]. Annotated by Azizollah Alizādeh. Tehrān: Entešārāt-e Ferdos.

Afif, Š. (2007/1385). Tārix-e Firuzšăhi [The History of Firuzšāhi]. Corrected by Velāyat Hosseyn. Introduction by Dr. Mohammad Reza Nasiri. Tehrān: Entešārāt-e Asātir.

Al-Kāteb al-Rajāni, F. (2004/1383). Samak Ayyār. Annotated by Seyyed Ali Šahāri. 2 Vols. Tehrān: Sedāy-e Moāsser.

Al-Madani Al-Tatavi, A. (Unspecified Date). Farhang-e Rašidi [The Lexicon of Rašidi]. [Written in 1064 Hegira (1654 C.E.)]. Four Volumes. Tehrān.

Anjavi Širāzi, M. Farhang-e Jahānigiri [The Lexicon of Jahānigiri]. Written in 1302 Hegira (1884 C.E.).

As'ad Gorgāni, F. (1970:1349): Veys va Rāmin. Tehrān: Entešārāt-e Bonyād-e Farhang Irān.

Asadi Tusi, H. (1938:1317). Garšāsbnāme. Annotated by Habib Yaghmai. Tehrān: Ketābfuruši va Čāpxāne Baruxim.

Asadi Tusi, A. (1986/1365). Loqat-e Fors. Annotated by Fath Mojtabāyi and Ali Ašraf Sādeqi. [Written in $5^{\text {th }}$ Century Hegira $\left(11^{\text {th }}\right.$ Century C.E.)]. Tehrān: Xārazmi.

Attār Neišāburi, A. (1993/1372). Manteq al-Teyr [Conference of the Birds]. Annotated by Seyyed Sadeq Goharin. Tehrān: Šerkat-e Entešāāāt-e Elmi va Farhangi.

Bahrām Paj̆dŏ, Z. (1965/1343). Ardāvirāfnāme [The book of Ardāvirāf]. Annotated by Rahim Afifi. Mashhad: Čāpxāne-ye Dānešgāh Mašhad. 
Bahrām Paǰdŏ, Z. (1960/1338). Zaratoštnāme [The Book of Zoroaster]. Annotated by Mohammad Dabir Siyāqi. Tehrān: Ketābxāne-ye Tahvari.

Beyhaqi Dabir, A. (2004/1383). Tārix-e Beyhaqi [The History of Beyhaqi]. Annotated by Ali Akbar Fayyaz. Mašhad: Danešgāh Ferdǒsi Mašhad.

Beiqami, M. (2002/1381). Dārābnāme. Corrected by Zabiollāh Safā. Corrected and Annotated by Zabihollah Safa. Two Volumes. Tehrān: Šerkat-e Entešārāte Elmi va Farhangi.

Dāstān-e Hosseyn Kord-e Šabestari [The Story of Hosseyn Kord Šabestari] (2003/1382). Annotated by Abbas Šabgāhi Šabestari. Tehrān: Moaseseye Entešārāt-e Farahāni.

Daqiqi Tusi, A. (1994/1373). Goštāsbnāme be Enzemām-e Farhang-e Basāmadi [Goštāsbnāme together with the Basamadi Lexicon]. Annotated by Mohammad Javād Šariat. Tehrān: Entešārāt Asātid.

Eskandar Beig Torkamān (2003/1382). Tārix-e Ālam Ārāye Abbāsi [The History of Ālam Ārāye Abbāsi]. Edited and annotated by Iraj Afs̄ār. 2 volumes. Tehrān: Entešārāt-e Amir Kabir.

Esterābādi, M. (1991/1370). Tārix-e Jahāngošāy-e Nāderi [The History of the World Conquest of Nader]. A Copy of the Illustrated Manuscript of 1757. Introduction by Abdolali Adib Barumand. Tehrān: Soruš.

Ferdŏsi, H. A. (1995/1384). Šāhnāme Ferdŏsi (bar Asās-e Nosxeye Mašhur-e be Čap-pe Mosko) [Šāhnāme Ferdŏsi (based on the version of the Manuscript known as published in Moscow)]. Tehrān: Entešārāt-e Alam.

Hakim, M. (Unspecified date). Koliyat-e Haft Jeldi Eskandarnāme: Sahebgaran Zowalgarenein Eskandar ben Dārāb ben Bahman ben Esfandiyār Ruintan [The Complete Seven Volumes of Eskandarnāme: Sahebgaran Zowalgarenein Alexander, the son of Dārāab, the son of Bahman, the son of the Invulnerable Esfandiyār]. From the Series of Legends of Oriental Pahlavān. Tehrān: Entešārāt-e Mohammad Hasan Sar Elmi.

Jonābodi, M. (1999/1378). Rozat al-Safaviye (Tārix-e Doreye Safaviye) [Rosat al-Safaviye the History of Safavid Era)]. Annotated by Qolāmrezā Tabātabā'i Majd. Tehrān: Entešārāt va Čāp-e Danešgāh-e Tehrān.

Manučehri Dāmqāni, A. (1983/1362). Aš’’ār-e Manučehri Dāmqāni [The Poems of Manučehri Dāmqāni]. Annotated by Mohammad Dabir Siyāqi. Tehrān: Entešārāt-e Amir Kabir.

Marvi Vazir Marv, M. (1985/1374). Ālam Ārāye Nāderi. Annotated by Dr. Mohammad Amin Riyāhi. Three Volumes. Tehrān: Entešāāât Elmi.

Mobārak Šāh Faxr-e Modabbar, M. (1967/1346). Ādāb al-Harb va al-al-Šojā-e [The Customs of War and Bravery]. Annotated by Ahmad Soheili Xānsari. Tehrān: Eqbāl.

Mohammad Pādešāh (1956/1335). Farhang-e Ānendrāj [The Lexicon of Ānendrāj]. Written by Mohammad Pādešāh known as Šād with the Assistence of his Two Brothers in India in 1306 Hegira (1888 C.E.). Seven Volumes. Under the Auspices of Mohammad Dabir Siyāqi. Tehrān: Ketābxāneye Xayyām.

Molavi, M. (2007/1385). Masnavi Ma’navi. Edited by Reynold A. Nicholson. Tehrān: Entešārāt Hermes.

Nāser Xosrŏ Qobādiyāni, A. (1985:1363). Safarnāme-ye Nāser Xosrŏ [The Journey Accounts of Nāser Xosrō]. Annotated by Mohammad Dabir Siyāqi. Tehrān: Ketābforuši Zavvār.

Nafisi, A. (1964/1343). Farhang-e Nafisi [Lexicon of Nafisi]. [Written during the Qājār Period]. Five Volumes. Tehrān: Ketābforuši Xayyām.

Nezāmi Ganje’i, N. (2007/1385a). Šarafnāme. Annotated by Hasan Vahid Dastgardi. Introduction by Sa’id Hamidiyān. Tehrān: Našr-e Afkār.

Nezāmi Ganje'i, N. (1999/1377). Haft Peykar. Annotated by Hasan Vahid Dastgardi. Introduction by Sa’id Hamidiyān. Tehrān: Našr-e Qatre.

Onsori Balxi, A. (1990/1369). Aš’ār-e Onsori Balxi [Poems of Onsori Balxi]. Moqaddame [Introduction] by Mohammad Dabir Siyāqi. Tehrān: Entešārāt-e Amir Kabir.

Resāle-ye Avval [First Treatise] (1985/1374). In: Ā'in Qalandari: Moštamel bar Čāhr Resāle dar Bāb-e Qalandari, Xāksāri, Ferqe-ye Ajam va Soxanvari [The Rules and Doctrines of Qalandari: Including Four Treatises with the Topics of Qalandari, Xāksāri, Ferqe-ye Ajjam, and Soxanvari]. Annotated by Seyyed Abutāleb Mir Ābedini and Mehran Afs̃āri. Tehrān: Entešārāt-e Farāravān, pp. 73-213.

Resāle-ye Čāhrom [Fourth Treatise] (1985/1374). In: Ā'in Qalandari: Moštamel bar Čāhr Resāle dar Bāb-e Qalandari, Xāksāri, Ferqe-ye Ajam va Soxanvari [The Rules and Doctrines of Qalandari: Including Four Treatises with the Topics of Qalandari, Xāksāri, Ferqe-ye Ajjam, and Soxanvari]. 
Annotated by Seyyed Abutāleb Mir Ābedini and Mehran Afšāri. Tehrān: Entešārāt-e Farāravān, pp. 333-457.

Romuz-e Hamze [Secrets of Hamze] (1940/1359 Hegira:224). Handwritten by Mohammad Ali Nāme. Tehrān: Šerkat-e Čāp-e Ketāb.

Rudaki, A. (2004/1382). Divān-e Rudaki Samarqandi [Antology of Rudaki Samarqandi]. Based on the Copy of Sa'id Nafisi. Tehrān: Entešārāt-e Negāh.

Sa'd Salmān, M. (1995/1374). Divān-e Mas'ud Sa'd Salmān (The Anthology of Mas'ud Sa'd Salmān) Annotated by Rašid Yāsemi. Tehrān: Mo'assese-ye Entešārāte-e Negāh.

Sa'di, M. A. (2005/1383). Koliyāt-e Sa'di [The Complete Works of Sa'di]. Annotated by Hasan Anvari. Tehrān: Našr-e Qatre.

Sabā, F. Šahanšahnāme. Handwritten Manuscript. Mashad: Astān-e Qods-e Razavi.

Šabānkāre'i, M. (2002/1381). Majma' al-Ansāb (Nimeye Aval). Edited by Mir Hashem Mohaddes. Tehrān: Amir Kabir.

Širuye Nāmdār (2005/1384). Tehrān: Entešārāt-e Qoqnŏs.

Tārix-e Sistān (1992/1381). [The History of Sistān]. Annotated by Malekalšoarā Bahār. Tehrān: Donyāye Ketāb.

Tabrizi, M. (1951/1330). Borhān-e Qāte'[The Ultimate Reasoning]. [This book was written in Hydarabad in 1062 Hegira (1652 C.E.)]. Annotated by Mohammad Mo'in. Four Volumes. Tehrān.

Tahvildār Esfahāni, H. (1964/1342). Jogrāfiyā-ye Esfahān: Jogrāfiyā-ye Tabi’i va Ensāni va Āmār-e Asnāf-e Šahr [The Geography of Isfahan: the Natural and Human Geography and the Statistics on Crafts from t he City]. Annotated by Manouchehr Sotude. Tehrān: Čāpxāne-ye Dānešgāh-e Tehrān.

Tarsusi, A. (1977/2536). Dārābnāme-ye Tarsusi. Annotated and Corrected by Zabiholla Safā. Tehrān. Bongāh-e Tarjome va Našr-e Ketāb.

Tartusi, A. (2001/1380). Abu Moslemnāme. Annotated by Hosseyn Esmā'ili. Four Volumes Tehrān: Entešārāt-e Moi'n, Našr-e Qatre, Anjoman-e Irānšenāsi dar Irān.

Xonji Esfahāni, F: (2003/1382). Tārix-e Ālam Āryā-ye Amini: Šarh-e Hokmrāni Salātin-e Āq-Quyunlu va Zohur-e Safaviān [The History of Ālam Äryā-ye Amini: Exposition of Sultans Aq-quyunlu's Ruling and Appearance of Safavid]. Qarn-e Nohom va Dahom Hejri [The Ninth and the Tenth Century Hegira] Edited by Mohammad Akbar Ašiq. Tehrān: Markaz-e Našr-e Mirās-e Maktub.

Yazdi, M. (1957/1336). Zafarnāme (Tārix-e Umumi Irān dar Doreye Teimuriyān) [Zafarnāme (The General History of Iran during Timurid Period]. Corrected and Annotated by Mohammad Abbāsi. Tehrān: Amir Kabir.

\section{Secondary Iranian Sources}

Farahvaši, B. (2002a/1381). Farhang Zaban Pahlavi [The Lexicon of Pahlavi Language]. Tehrān: Entešāāăt-e Danešgāh-e Tehrān.

Farahvaši, B. (2002b/1381). Farhang Farsi be Pahlavi [The Lexicon of Persian into Pahlavi]. Tehrān: Entešārāt-e Dānešgāh Tehrān.

Ma'tufi, A. (1999/1378). Tārix-e Čāhr Hezār Sāle-ye Arteš Irān: Az Tamaddon-e Ilām Tā 1320 Xoršidi, Jang-e Irān Va Arāq [The Four-thousand-year History of the Iranian Military: From the Elamite Civilization to the Year 1320, The Iran and Iraq War]. Two volumes. Tehrān: Entešārāt-e Imān.

Romanowsky, D. (1967c/1346). Tārixče-ye Aslahe-ye Sard dar Irān [The Short History of Cold Weapons in Iran]. [Part 3]. In: Majjale-ye Barrasihāye Tārixi [Journal of Historical Research], Number 6, Year 2, pp. 89-112.

Romanowsky, D. (1967b/1346). Tārixče-ye Aslahehā-ye Sard dar Irān [The Short History of Cold Weapons in Iran]. [Part 2]. In: Majjale-ye Barrasihāye Tārixi [Journal of Historical Research], Number 5, Year 2, pp. 76-100.

Romanowsky, D. (1967a/1346). Tārixče-ye Aslahehā-ye Sard dar Irān [The Short History of Cold Weapons in Iran]. In: Majjale-ye Barrasihāye Tārixi [Journal of Historical Research] [Part 1], Number 3-4, Year 2, pp. 263-280.

Semsār, M. H. (1997/1377). Dāeratolmaāref-e Bozorg-e Eslāmi [The Great Islamic Encyclopaedia]. The Eight Volume. Edited by Kazem Musavi Bojnordi. Tehrān: Markaz-e Dāeratolmaāref-e Bozorg-e Eslāmi. 
Šahidi, E. (2001/1380). Ta'ziyeh va Ta 'zieyexāni: Az Āqāz Tā Pāyān Doreye Qājār Dar Tehrān [Ta'ziyeh and Ta'zieyexāni in Tehran: Research on the Shi'a Indigenous Drama of Ta'ziyeh from the Beginning to the End of Qajar Era]. Tehran: Khojaste.

Zokā, Y. (1971/1350). Arteše Šāhanšāhi Iran Az Kuroš Ta Pahlavi [The Royal Army of Iran from Kurosh to Phalavi]. Tehrān: Čāpxāne-ye Vezārat-e Farhang va Honar.

\section{Secondary International Sources}

Chodynski, A. (ed.) (2000). Persian and Indo-Persian Arms and Armour of $16^{\text {th }}-19^{\text {th }}$ Century from Polish Collections. Malbork: Muzeum Zamkowe w Malborku.

Grancsay, S. V. (1957). The New Galleries of Oriental Arms and Armour. The Metropolitan Museum of Art (New York) N.S. 16: 241-256.

Harper, P. O. (1985). The Ox-headed Mace in Pre-Islamic Iran. Acta Iranica, 24. 2ieme série, vol. X. Papers in Honour of Mary Boyce: 247-259.

Ibn-Munqidh, U. (1987). An Arab-Syrian Gentleman and Warrior in the Period of the Crusades: Memoirs of Usamah Ibn-Munqidh. Pincton: Princton University Press.

Kobylinski, L. (2000). Persian and Indo-Persian Arms. In: Antoni Romuald Chodynski (ed.). Persian and Indo-Persian Arms and Armour of $16^{\text {th }}-19^{\text {th }}$ Century from Polish Collections. Malbork: Muzeum Zamkowe w Malborku, pp . 57-74.

Moshtagh Khorasani, M. (2006). Arms and Armour from Iran: the Bronze Age to the End of the Qajar Period. Tübingen: Legat Verlag.

Nicolle, D. (2002). Jawshan, Cuirie and Coats-of-Plates: An Alternative Line of Development for Hardened Leather Armour. In: David Nicolle (ed.). A Companion to Medieval Arms and Armour. Woodbridge: The Boydell Press, pp. 179-221.

-(1998) Armies of the Caliphates 862 - 1098. Oxford: Osprey Publishing Ltd.

Zeller, R. and Rohrer, E. F. (1955). Orientalische Sammlung Henri Moser-Charlottenfels:Beschreibender Katalog der Waffensammlung. Bern: Kommissionsverlag von K.J. Wyß Erben AG.

Recibido: 28/09/2009

Aceptado: 16/11/2010 